Document downloaded from:

http://hdl.handle.net/10251/51732

This paper must be cited as:

Sospedra, J.; Falco, S.; Morata T.; Gadea, I.; Rodilla, M. (2015). Benthic fluxes of oxygen and nutrients in sublittoral fine sands in a north-western Mediterranean coastal area. Continental Shelf Research. 97:32-42. doi:10.1016/j.csr.2015.02.002.

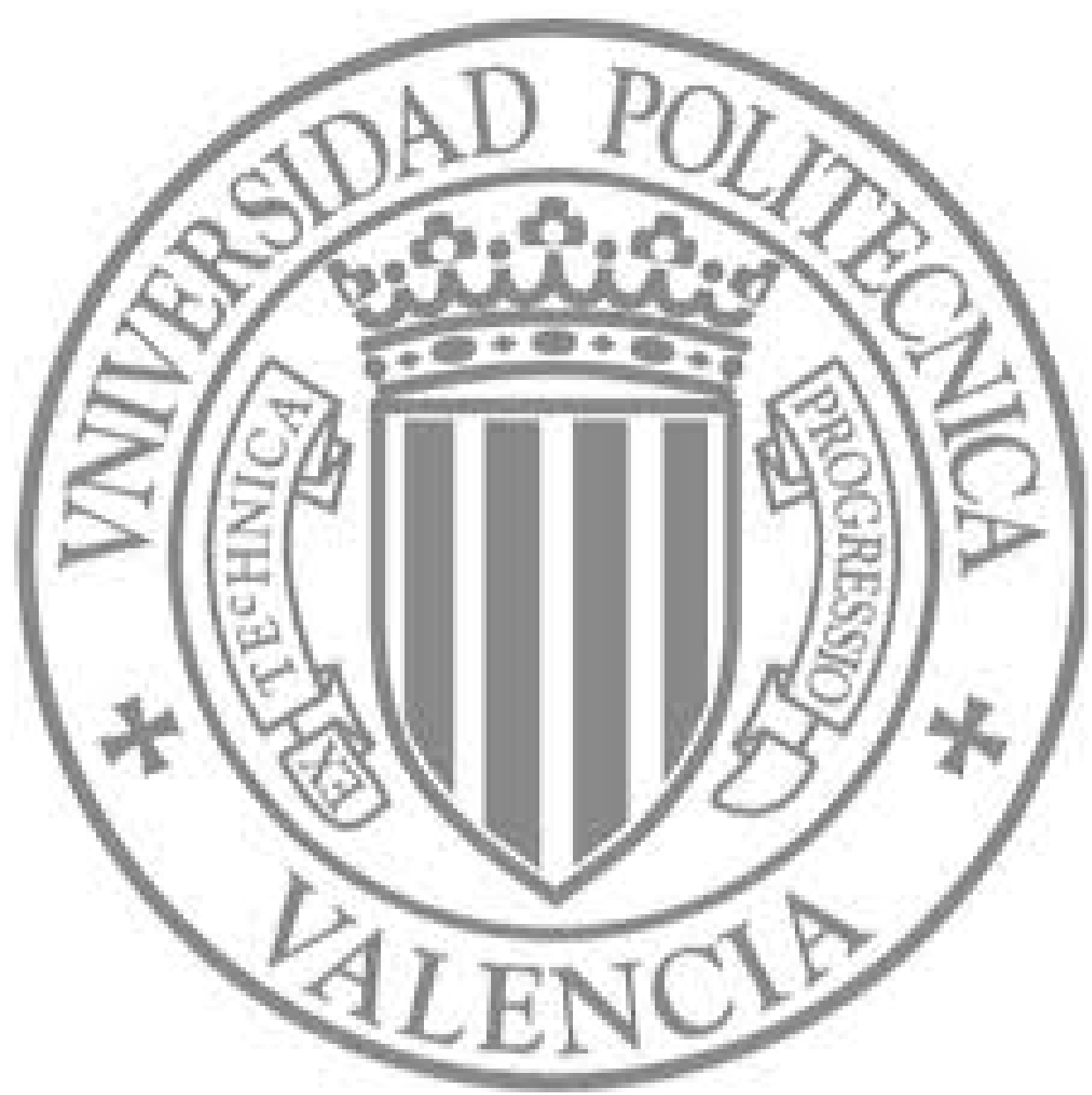

The final publication is available at

http://dx.doi.org/10.1016/j.csr.2015.02.002

Copyright Elsevier 


\title{
Benthic fluxes of oxygen and nutrients in sublittoral fine sands in a north-western Mediterranean coastal area
}

J. Sospedra*, S. Falco, T. Morata, I. Gadea, M. Rodilla

Institut d'Investigació per a la Gestió Integrada de zones Costaneres (IGIC), Universitat Politècnica de València, C/ Paranimf, 1. 46730 Grau de Gandia, Spain

*corresponding author. Tel.: +349628494 48; fax: +34962849309

E-mail address: jasoscis@epsg.upv.es (J. Sospedra).

\begin{abstract}
Traditionally, benthic metabolism in sublittoral permeable sands have not been widely studied, although these sands can have a direct and transcendental impact in coastal ecosystems. This study aims to determine oxygen and nutrient fluxes at the sediment-water interface and the study of possible interactions among environmental variables and the benthic metabolism in well-sorted fine sands. Eight sampling campaigns were carried out over the annual cycle in the eastern coast of Spain (NW Mediterranean) at 9 meters depth station with permeable bottoms. Water column and sediment samples were collected in order to determine physico-chemical and biological variables. Moreover, in situ incubations were performed to estimate the exchange of dissolved solutes in the sediment-water interface using dark and light benthic chambers. Biochemical compounds at the sediment surface ranged between 160-744 $\mu \mathrm{g} \mathrm{g}^{-1}$ for proteins, 296-702 $\mu \mathrm{g} \mathrm{g}^{-1}$ for carbohydrates, and between 327-1224 $\mu \mathrm{g} \mathrm{C} \mathrm{g}^{-1}$ for biopolymeric carbon. Chloroplastic pigment equivalents in sediments were mainly composed by chlorophyll $a\left(1.81-2.89 \mu \mathrm{g} \mathrm{g}^{-1}\right)$. These sedimentary organic descriptors indicated oligotrophic conditions according to the biochemical approach used. In this sense, the most abundant species in the macrobenthic community were sensitive to organic enrichment. In dark conditions, benthic fluxes behaved as a sink of oxygen and a source of nutrients. Oxygen fluxes (between -26610 and $\left.-10635 \mu \mathrm{mol} \mathrm{m} \mathrm{m}^{-2} \mathrm{~d}^{-1}\right)$ were related with labile organic fraction $(\mathrm{r}=-0.86, p<0.01$ with biopolymeric carbon; $\mathrm{r}=-0.91, p<0.01$ with chloroplastic pigment equivalents). Daily fluxes of dissolved oxygen, that were obtained by adding light and dark fluxes, were only positive in spring campaigns $\left(6966 \mu \mathrm{mol} \mathrm{m}^{-2} \mathrm{~d}^{-1}\right)$ owing to the highest incident irradiance levels $(\mathrm{r}=0.98, p<0.01)$ that stimulate microphytobenthic primary production. Microphytobenthos played an important role on benthic metabolism and was the main primary producer in this coastal ecosystem. However, an average annual uptake of $31 \mathrm{mmol} \mathrm{m}^{-2} \mathrm{~d}^{-1}$ of oxygen and a release of DIN and $\mathrm{Si}(\mathrm{OH})_{4}\left(329\right.$ and $68 \mathrm{mmol} \mathrm{m}^{-2} \mathrm{~d}^{-1}$ respectively) were estimated in these bottoms, which means heterotrophic conditions.
\end{abstract}




\section{Keywords}

Sediment-water interface, microphytobenthos, well-sorted fine sands, benthic metabolism.

\section{Introduction}

Continental shelf ecosystems are characterized by intense and complex interactions where continental, oceanic and atmospheric processes take place together. These ecosystems receive most of the inputs from continents, atmosphere, deeper ocean waters as well as from marine sediments. Due to human development, nutrient and organic matter inputs have been increasing since the second half of the $20^{\text {th }}$ century (Smith, 2002), especially nitrogen and phosphorus. This process of organic matter and nutrient enrichment, known as eutrophication, is one of the most important current problems related to marine ecosystems (Smith, 2002). The organic and nutrient charge in coastal areas are transcendental since enhance and regulate primary producers (Smayda, 2005). Nevertheless, an intense or continuous organic or nutrient discharge could cause the ecosystem degradation (Cloern, 2001).

Nutrient inputs enable approximately $20 \%$ of global pelagic primary production to take place on the continental shelves (Jahnke, 2010). A large fraction of this pelagic primary production, as well as organic inputs from continent, can reach the sediment surface due to the shallow depth in the inner shelves (Huettel et al., 2014). At surface sediments, an excess of organic material can promote benthic primary production (Karydis and Kitsiou, 2012), organic matter accumulation and even can turn the seafloor anoxic (Morata et al., 2012). Organic matter present in the sediment is the main driving force of mineralization in inner shelve bottoms, which organic and nutrient production can be transported to water column by advective and diffusive transport or fixed by benthic photosynthesizers. In this sense, benthic nutrient regeneration can play a major role in the nutrient supply that can contribute to primary production. Many authors, such as Loassachan et al. (2009), Mermillod-Blondin et al. (2008), and Sarker et al. (2009), have described the large number of factors that regulate the availability and regeneration of nutrients in inner shelve bottoms. The main factors are microbial community (Jørgensen, 2006), benthic macrofauna (Mermillod-Blondin and Rosenberg, 2006), quantity and quality of organic matter (Pastor et al., 2011) and benthic primary producers (Mermillod-Blondin et al., 2008) such as seagrasses, macroalgae, as well as microalgae, although a great number of environmental ones, such as temperature or light, can affect all of these. 
The study of benthic metabolism and nutrient exchange at the sediment-water interface in continental shelves have been focused on muddy and organic-rich sediments such as estuaries (Pratihary et al., 2009), salt marshes (Ferrón et al., 2009a), aquaculture production areas (Morata et al., 2012) or coastal lagoons (De Vittor et al., 2012). Permeable sands have been neglected based on the belief that intense exchanges across sediment-water interface and biological activity require high levels of organic matter, despite the fact that these permeable bottoms cover $70 \%$ of all continental shelves (Boudreau et al., 2001) and 4\% of the ocean floor (Hall, 2002). However, recent studies suggest that permeable bottoms act as a biocatalytic filters with high reaction rates and intense recycling comparable to the metabolism in low-permeable sediments (see Huettel et al., 2014, and references therein). Furthermore, shallow water column depth in the inner shelf allows sunlight to reach these sublittoral bottoms enabling benthic photosynthesis (Huettel et al., 2014). In particular, microphytobenthos does not require high conservatives light fluxes (Gattuso et al., 2006), hence, these phototrophs can cover wide areas of permeable sublittoral sediments. Microphytobenthos constitutes a food source for benthic feeders (Nozais et al., 2005) and can contribute up to $50 \%$ of total primary production (Perissinotto et al., 2002). During the last few decades, some works have been carried out on permeable sublittoral sands and oligotrophic zones e.g. in the South Atlantic Bight studying microphytobenthic primary production (Jahnke et al., 2005; 2008) or in the Mediterranean Sea over Posidonia oceanica meadows (Barrón et al., 2006). However, not many studies have considered the entire benthic ecosystem structure including physical, chemical, biochemical descriptors and biological variables involved in the study of the benthic metabolism in permeable sublittoral sands.

The aim of this work is therefore, to study the exchange of oxygen and nutrients across the sediment-water interface in order to determine the benthic metabolism in sediments composed by permeable sublittoral sands over the annual cycle. To achieve this objective we used in situ incubations employing light and dark chambers over the annual cycle. Likewise, it took into account the study of possible interactions among environmental variables and the identification of those which were the most influential on the benthic metabolism.

\section{Material and methods}

\subsection{Study site}

The study area falls within the Gulf of Valencia (Spain) in the Western Mediterranean. Specifically, the sampling station was in Gandia, in the southern part of the Gulf of Valencia (Figure 1). At the point where the station is 
located $\left(39^{\circ} 00^{\prime} 37^{\prime \prime} \mathrm{N}, 00^{\circ} 09^{\prime} 19^{\prime \prime} \mathrm{W}\right)$, the water column is approximately $9 \mathrm{~m}$ in depth and the seabed is composed of well-sorted fine sands. This biocenosis is spread over wide areas of the Mediterranean Sea (BellanSantini et al., 1994) and it commonly found around the Eastern Iberian Peninsula coastline (De-la-Ossa-Carretero et al., 2009). In fact, this biocenosis covers roughly over $640 \mathrm{~km}^{2}$ of the Gulf of Valencia, from the marine mapping elaborated by MAGRAMA (2010). Well-sorted fine sands are composed of fine and homogeneous sands and inhabited by annelids, molluscs, crustaceans and equinoderms.

Fig. 1. Sampling site at the southernmost sector of the Gulf of Valencia (Western Mediterranean).

This study included eight different sampling campaigns over the annual cycle. Sampling campaign dates were chosen to take into account variables and factors that influence biogeochemical processes such as temperature and solar radiation. Therefore, the chosen dates included the maximum and minimum of these factors, however, sampling campaigns only could be carry out under calm sea conditions in order to guarantee the correct deployment of instruments and team work. The sampling campaigns took place: $5^{\text {th }}$ August 2009 (Summer 2009),

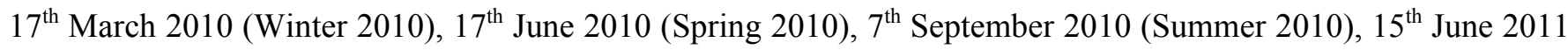
(Spring 2011), 30 ${ }^{\text {th }}$ August 2011 (Summer 2011), $7^{\text {th }}$ December 2011 (Autumn 2011) and $15^{\text {th }}$ March 2012 (Winter 2012). In each sampling campaign, samples of water and sediment were collected in order to determine different physical, chemical and biological variables. In the water column the variables studied were temperature, suspended solids (SS), dissolved oxygen (DO), ammonium $\left(\mathrm{NH}_{4}{ }^{+}\right)$, nitrite plus nitrate $\left(\mathrm{NO}_{2}{ }^{-}+\mathrm{NO}_{3}{ }^{-}\right)$, phosphate $\left(\mathrm{PO}_{4}{ }^{3-}\right)$, total phosphorus (TP), silicic acid $\left(\mathrm{Si}(\mathrm{OH})_{4}\right)$, chlorophyll (WChl- $a$ ) and transparency. In the sediment we determined incident irradiance at the surface of sediment $\left(\mathrm{I}_{\mathrm{z}}\right)$, redox potential $(\mathrm{Eh})$, granulometric composition, organic matter (OM), chlorophyll (SChl-a), phaeopigments (Phaeo), proteins (PRT), carbohydrates (CHO), lipids (LIP) and the benthic macrofauna composition. Likewise, in situ incubations were also conducted using benthic chambers to study DO, $\mathrm{NH}_{4}{ }^{+}, \mathrm{NO}_{2}{ }^{-}+\mathrm{NO}_{3}{ }^{-}, \mathrm{PO}_{4}{ }^{3-}$ and $\mathrm{Si}(\mathrm{OH})_{4}$ fluxes across the sediment-water interface.

\subsection{Sample collection}

Water samples were taken using a Van Dorn bottle every $3 \mathrm{~m}$. However, bottom water samples were collected at half a metre above the seabed surface in order to prevent sediment resuspension. 
In the sediment, 12 undisturbed samples were taken by SCUBA divers using corers with a height of $30 \mathrm{~cm}$ and an internal diameter of $6.5 \mathrm{~cm}$. Redox potential was measured immediately on all cores collected in each sampling campaign. Six of them were used for the study of the physico-chemical variables in the uppermost $1 \mathrm{~cm}$ layer, which were carefully stored in the dark and placed in a vertical position. The other six cores used for the macrofauna study were processed immediately in situ.

\subsection{Benthic flux chamber experiments}

Benthic chambers, similar to those used by Freitas et al. (2008) and Morata et al. (2012; 2014), were employed for the in situ calculation of the fluxes of $\mathrm{DO}, \mathrm{NH}_{4}{ }^{+}, \mathrm{NO}_{2}{ }^{-}+\mathrm{NO}_{3}{ }_{3}^{-}, \mathrm{PO}_{4}{ }^{3-}$ and $\mathrm{Si}(\mathrm{OH})_{4}$ at the sediment-water interface. Two types of chambers were employed: light in order to study the role of primary production, and dark where photosynthesis is inhibited. Three replicas were used for each type of chamber in order to minimize the effect of the sediment heterogeneity. Each semi-spherical chamber had an incubated water volume of 16.71 , covering a sediment surface area of $0.125 \mathrm{~m}^{2}$. These were carefully placed on the sediment surface by SCUBA divers and incubations took place from sunrise to sunset, approximately 10-13 hours depending on the season. An aliquot of $180 \mathrm{ml}$ was withdrawn from each chamber, after the homogenization of the incubated water using a manual stirring in order to prevent concentration gradients, every 2-2.5 hours. Fluxes were calculated from the slope of a linear fit of the concentration distribution, following the methodology employed by Morata et al. $(2012 ; 2014)$. Once fluxes in both light and dark conditions had been measured, the mean daily flux $\left(\mathrm{F}_{\mathrm{D}}\right)$ was calculated using the equation used by Nizzoli et al. (2007):

$$
\mathrm{F}_{\mathrm{D}}=\left(\mathrm{F}_{\mathrm{L}} / 24\right) \cdot f+\left(\mathrm{F}_{\mathrm{N}} / 24\right) \cdot(24-f)
$$

where $F_{L}$ is the flux in light chambers, equivalent to daytime conditions, $F_{N}$ is in dark chambers, representing flux under nighttime conditions and $f$ is the photoperiod. In the case of DO, the flux in light chambers meant Net Primary Production (NPP), whereas Gross Primary Production (GPP) was NPP plus the flux of DO in dark conditions (Ní Longphuirt et al., 2007).

\subsection{Sample analyses}

Vertical water profiles were undertaken in situ with an YSI proODO probe (Yellow Springs, Ohio, USA), measuring temperature and DO. Not more than an hour elapsed from the time samples were collected to their 
delivery at the laboratory where they were processed. In the laboratory, water samples for the analysis of dissolved nutrients were filtered through a $0.45 \mu \mathrm{m}$ pore diameter cellulose acetate filter and frozen in plastic bottle for later analysis, except $\mathrm{NH}_{4}{ }^{+}$that was analysed on the same day. Nutrients $\left(\mathrm{NH}_{4}{ }^{+}, \mathrm{NO}_{2}{ }^{-}+\mathrm{NO}_{3}{ }^{-}, \mathrm{PO}_{4}{ }^{3-}\right.$ and $\left.\mathrm{Si}(\mathrm{OH})_{4}\right)$ were analysed according to Aminot and Chaussepied (1983). The precision of these methods was $5 \%$ for $\mathrm{NH}_{4}{ }^{+}, \mathrm{NO}_{2}{ }^{-}$ $+\mathrm{NO}_{3}{ }^{-}$and $\mathrm{PO}_{4}{ }^{3-}$ whereas for $\mathrm{Si}(\mathrm{OH})_{4}$ was $3 \%$. Chlorophyll $a$ in the water (WChl-a) and the suspended solids (SS) were analysed following the methodology described in APHA et al. (2012). Dissolved inorganic nitrogen (DIN) was calculated as the sum of $\mathrm{NH}_{4}{ }^{+}$and $\mathrm{NO}_{2}{ }^{-}+\mathrm{NO}_{3}{ }^{-}$. In order to determine the different variables of the incubated water during the in situ experiments, the same methodology as in the case of water column was used, but with adaptations for microvolumes. For these incubations, DO was determined in accordance with the procedure described in Aminot and Chaussepied (1983), based on Winkler's classic iodine-measuring method. The precision was $0.5 \%$.

Granulometric composition was performed by sieving the uppermost sediment layer through different meshes to sort the sediment using Wentworth scale (Shepard, 1954). Irradiance on the sediment surface $\left(I_{z}\right)$ was calculated, based on the transparency of the water column from Secchi disc and the atmospheric solar radiation $\left(\mathrm{I}_{0}\right)$ following Lorenti and De Falco (2004) at the time benthic chambers were sampled. From $I_{z}$ punctual values were obtained a diurnal average value $\left(\overline{\mathrm{I}}_{\mathrm{z}}\right)$. $\mathrm{I}_{\mathrm{o}}$ data were provided by the weather station located on the university campus in Gandia, less than $2 \mathrm{~km}$ from the sampling station. Redox potential (Eh, $\mathrm{n}=12)$ was measured on the deck immediately after their collection using a Pt electrode Crison PH25 5261 (Crison, Spain) which was inserted into the cores $0.5 \mathrm{~cm}$. Organic matter $(\mathrm{OM}, \mathrm{n}=3)$ was measured by combustion using a $10 \% \mathrm{HCl}$ pre-treatment to remove carbonates (Dell'Anno et al., 2002) which could interfere with organic matter assessment. Chlorophyll $a$ (SChl-a), phaeopigments (Phaeo), proteins (PTR), carbohydrates (CHO), and lipids (LIP) in sediments were analysed according to Pusceddu et al. (2004). These analyses were carried out in 9 replicates for each biochemical variable measured. Chloroplastic pigment equivalents (CPE) were defined as the sum of SChl- $a$ and Phaeo. PRT, CHO and LIP concentrations were expressed in bovine serum albumin, glucose and tripalmitine respectively and later converted to carbon equivalents using the following conversion factors: $0.49,0.40$ and $0.75 \mu \mathrm{g} \mathrm{C} \mu \mathrm{g}^{-1}$, respectively (Fichez, 1991). The sum of these variables was referred to as the biopolymeric fraction of organic carbon (BPC). The composition and density of the benthic macrofauna was also studied. To this end, 6 cores was sieved separately 
using a $500 \mu \mathrm{m}$ mesh in each sampling campaign and submerged in a 7\% magnesium chloride solution for 30 minutes as an anaesthetic and preserved in 5-10\% buffered formaldehyde (Castelli et al., 2004) until the macrofauna could be determined to the lowest possible taxonomic level.

The Sperman-Rank correlation analysis was performed in order to test relationships between all variables studied and was carried out on SPSS. Kruskal-Wallis non-parametric tests were used to assess significant differences between median values of the different variables analysed in the water column, sediment and benthic chambers. The factor chosen was the season (winter, spring, summer or autumn). Moreover, in the water column data set was another chosen factor, the depth divided into four different groups ( $0 \mathrm{~m}, 3 \mathrm{~m}, 6 \mathrm{~m}$ and $9 \mathrm{~m}$ depth). These statistical tests were carried out on Statgraphics. A Factor Analysis was carried out in order to explain and reduce variables to a lower number of unobserved latent variables employing SPSS.

\section{Results}

\subsection{Water column and sediment}

Table 1 shows maximum, minimum and average values of the variables studied in the water column for every sampling campaign. Kruskall-Wallis test indicated no statistical differences between the four sampled depths in the water column for any physical and chemical variables although there were statistical differences among seasons for temperature, SS, DO, $\mathrm{PO}_{4}{ }^{3-}, \mathrm{TP}$ and WChl-a. Temperature ranged widely during the annual cycle showing significant differences between the four seasons $(p<0.01)$. SS did not show large variations throughout the annual cycle although both winter campaigns presented the highest concentrations, between 12 and $14 \mathrm{mg} 1^{-1}$, which represented significant differences in respect to Spring and Autumn campaigns $(p<0.01)$. The maximum value of DO $(288$ and $306 \mu \mathrm{M})$ at wintertime, with minimum values in summer and spring campaigns (219 and $225 \mu \mathrm{M}$ respectively). Winter DO levels were statistically the highest, and summer and spring values the lowest $(p<0.01)$. Nitrogen compounds did not show wide variations between different campaigns nor were statistical differences detected (DIN, $p=0.06 ; \mathrm{NH}_{4}^{+}, p=0.45 ; \mathrm{NO}_{2}{ }^{-}+\mathrm{NO}_{3}{ }^{-}, p=0.12$ ). DIN showed the highest level in Spring 2010 with average value of $7.4 \mu \mathrm{M}$. $\mathrm{NH}_{4}{ }^{+}$and $\mathrm{NO}_{2}{ }^{-}+\mathrm{NO}_{3}{ }^{-}$values ranged from below the detection threshold $(<0.1 \mu \mathrm{M})$ to 3.0 and $11.6 \mu \mathrm{M}$ for $\mathrm{NH}_{4}{ }^{+}$and $\mathrm{NO}_{2}{ }^{-}+\mathrm{NO}_{3}{ }^{-}$respectively. Highest $\mathrm{PO}_{4}{ }^{3-}$ levels were observed in Summer 2009 which was statistically higher than the autumn and winter concentrations $(p=0.03)$. Significant differences were detected 
between TP levels in winter and summer $(p<0.01)$, reaching its maximum in both winter sampling campaigns. $\mathrm{Si}(\mathrm{OH})_{4}$ did not show significant differences between the seasonal medians $(p=0.43)$. WChl- $a$ was present in greater quantities in Summer 2009, Winter 2010 and Winter 2012. This led to detection of significant differences between winter, spring and autumn $(p<0.01)$.

\section{Table 1}

Averages and ranges of variables measured in water column in each sampling campaign.

Sediment variables studied did not range widely between different campaigns, so there were no statistical differences between seasons according to Kruskal-Wallis test. Sediments were composed predominantly of fine sand and very fine sand, both classes together represented about $90 \%$ of total mass (Table 2). On the other hand, fine-grained sediment (formed by silt and clay) ranged between 2.3 and 5.1\% in Spring 2011 and Winter 2010 respectively. $\overline{\mathrm{I}}_{\mathrm{z}}$ reached its maximum level in both spring campaigns whereas Winter 2010 and Winter 2012 were the lowest. Positive Eh values were always found in the uppermost sediment layer, ranging between 13 and 120 $\mathrm{mV}$ (Table 2). It can be observed in Table 3 that OM reached its maximum level in Summer $2010(1.40 \%)$ and its lowest value was observed in Summer $2011(0.52 \%)$. SChl- $a$ did not demonstrate great variation between the different sampling campaigns, but Phaeo had a maximum value of $1.93 \mu \mathrm{g} \mathrm{g}^{-1}$ recorded in Spring 2010 and a minimum of $0.45 \mu \mathrm{g} \mathrm{g}^{-1}$ in Autumn 2011. The sum of these two phytopigments, CPE, showed a similar pattern to Phaeo reaching a maximum concentration in Spring 2010 and a minimum in Autumn 2011. PRT ranged widely between different campaigns. The maximum was reached in Winter 2010 and Summer 2011 with values above 700 $\mu \mathrm{g} \mathrm{g}^{-1}$. CHO varied similarly to PRT, between 296 and $702 \mu \mathrm{g} \mathrm{g}^{-1}$ in Summer 2011 and Winter 2010 respectively. In spite of the fact that LIP concentration presented a peak value in Spring $2010\left(1113 \mu \mathrm{g} \mathrm{g}^{-1}\right)$, this compound was generally lower compared to PRT and CHO ranging between 110 and $302 \mu \mathrm{g} \mathrm{g}^{-1}$ (Table 3). The sum of the three main biochemical compounds (PRT, CHO and LIP) was between 327 and $1224 \mu \mathrm{g} \mathrm{C} \mathrm{g}^{-1}$.

\section{Table 2}

Physico-chemical characteristics of surface sediment for each campaign.

\section{Table 3}

Biochemical variables and standard deviation measured at the superficial sediment layer in each sampling campaign.

Most of campaigns presented well-developed patchy distribution of microphytobenthos over the sediment surface. Benthic macrofauna was composed of 96 different taxas, 44 of which corresponded to the Phylum Annelida (Class 
Polychaeta), 27 taxas were molluscs, 19 Arthropoda (Subphylum Crustacea) and the remaining taxas corresponded to Echinodermata, Nematoda, Nemertea, Sipuncula and Chaetognata. Maximum species richness was in Winter 2012 with 38 taxas whereas the minimum number was observed in Winter 2010 (Figure 2a). In four sampling campaigns, Polychaeta was the most important macrobenthic group for its density, which achieved values between 352 and 3566 ind $\mathrm{m}^{-2}$ (Figure $2 \mathrm{~b}$ ), representing $47-71 \%$ of the macrobenthic community in these campaigns. In Winter 2010 and Spring 2010, macrobenthic community was dominated by molluscs, specifically by small Spisula subtruncata bivalves with densities over 200000 ind $\mathrm{m}^{-2}$ in Winter 2010. On the other hand, crustaceans were the dominant taxonomic group in Summer 2011 and Winter 2012 with 53 and 68\% of the total abundance respectively. The most abundant taxas in this biocenosis were polychaetes Magela filiformis and Paradoneis armata, the crustacean Apseudes bacescui and the mollusc Spsisula subtruncata. Species richness, density of the different taxonomic groups and total macrofauna density also did not show statistical differences between seasons.

Fig.2. A) Species richness of benthic macrofauna and B) macrofauna density in sampling station sediments in each campaign.

\subsection{Benthic fluxes}

DO fluxes in the dark chambers were negative in all campaigns, especially Spring 2010 with $-26610 \mu \mathrm{mol} \mathrm{m}^{-2} \mathrm{~d}^{-1}$ (Figure 3). By contrast, in the light chambers there was a net production in all sampling campaigns carried out with higher values also in Spring $2010\left(28734 \mu \mathrm{mol} \mathrm{m}^{-2} \mathrm{~d}^{-1}\right)$. GPP in Spring 2010 was the highest $\left(2306 \mu \mathrm{mol} \mathrm{m}^{-2} \mathrm{~h}^{-1}\right)$, followed by Summer $2011\left(1664 \mu \mathrm{mol} \mathrm{m}^{-2} \mathrm{~h}^{-1}\right)$, Winter $2010\left(1582 \mu \mathrm{mol} \mathrm{m}^{-2} \mathrm{~h}^{-1}\right)$ and Spring $2011\left(1422 \mu \mathrm{mol} \mathrm{m} \mathrm{m}^{-2}\right.$ $\mathrm{h}^{-1}$ ). On the other hand, Summer 2010 and Autumn 2011 presented the lowest GPP, 633 and $611 \mu \mathrm{mol} \mathrm{m} \mathrm{m}^{-2} \mathrm{~h}^{-1}$ respectively.

Fig. 3. Benthic fluxes of A) dissolved oxygen (DO), B) ammonium $\left(\mathrm{NH}_{4}{ }^{+}\right)$, C) nitrite and nitrate $\left(\mathrm{NO}_{2}{ }^{-}+\mathrm{NO}_{3}{ }^{-}\right)$, D) dissolved inorganic nitrogen (DIN), E) phosphate $\left(\mathrm{PO}_{4}{ }^{3-}\right)$ and $\mathrm{F}$ ) silicic acid $\left(\mathrm{Si}(\mathrm{OH})_{4}\right)$ in dark (grey bars) and light chambers (white bars) with their standard deviation in the eight sampling campaigns. Black diamonds represent daily fluxes.

With regard to nutrients, there was a release of DIN in darkness in each campaign from 137 to $2638 \mu \mathrm{mol} \mathrm{m}^{-2} \mathrm{~d}^{-1}$. $\mathrm{NH}_{4}{ }^{+}$and $\mathrm{NO}_{2}{ }^{-}+\mathrm{NO}_{3}{ }^{-}$fluxes were also positive in dark conditions with two exceptions, Spring 2010 and Summer 2010, when $\mathrm{NO}_{2}{ }^{-}+\mathrm{NO}_{3}{ }^{-}$fluxes could not be determined. During the latter campaigns, $\mathrm{NO}_{2}{ }^{-}+\mathrm{NO}_{3}{ }^{-}$concentrations were found to be below the detection threshold of the technique employed in all of the aliquots extracted from the chambers, just as in the water column levels. In light incubations positive DIN fluxes were detected in seven 
campaigns. Summer 2010 was unique in that there was an uptake of $446 \mu \mathrm{mol} \mathrm{m}{ }^{-2} \mathrm{~d}^{-1}$. In the case of $\mathrm{NH}_{4}^{+}$, only in Spring 2011 an influx was calculated whilst in four campaigns negative fluxes of $\mathrm{NO}_{2}^{-}+\mathrm{NO}_{3}^{-}$were observed (Figure 3). $\mathrm{PO}_{4}{ }^{3-}$ fluxes in dark and light chambers were low in comparison with the remaining fluxes. In dark conditions, fluxes were close to zero, with the flux in Winter 2010 standing out with a value of $-10 \mu \mathrm{mol} \mathrm{m}^{-2} \mathrm{~d}^{-1}$ and Summer 2011 with $27 \mu \mathrm{mol} \mathrm{m}-{ }^{2} \mathrm{~d}^{-1}$ (Figure 3). A slight release into the water column of 6 and $7 \mu \mathrm{mol} \mathrm{m} \mathrm{m}^{-2}$ was observed in light conditions only in two summer campaigns (Summer 2009 and Summer 2011). Whereas in other campaigns these fluxes were negative or close to zero. In dark conditions, $\mathrm{Si}(\mathrm{OH})_{4}$ effluxes were observed in seven of the eight campaigns showing a maximum release in Winter 2010 with $1720 \mu \mathrm{mol} \mathrm{m} \mathrm{d}^{-2}$ (Figure 3). The remaining campaign, Summer 2009, presented a negligible negative flux of $-24 \mu \mathrm{mol} \mathrm{m}^{-2} \mathrm{~d}^{-1}$. Conversely, $\mathrm{Si}(\mathrm{OH})_{4}$ light fluxes were negative in seven campaigns with the Summer 2009 flux being the most negative with an influx of $-1212 \mu \mathrm{mol} \mathrm{m}^{-2} \mathrm{~d}^{-1}$. A release to the water column was calculated only in Winter 2010 (Figure 3).

In Figure 3, the estimated daily fluxes $\left(\mathrm{F}_{\mathrm{D}}\right)$ from the equation employed by Nizzoli et al. (2007) can be observed. Subsequently, these daily fluxes were used to calculate seasonal averages (Table 4). In the case of DO, there was a net production of this molecule over a whole day in both spring campaigns with an average of $6966 \mu \mathrm{mol} \mathrm{m}^{-2} \mathrm{~d}^{-1}$. In contrast, in the other seasons an uptake by the sediment was detected. DIN positive daily fluxes were estimated for the four seasons, showing the highest value in autumn. However, some campaigns presented negative daily fluxes for $\mathrm{NH}_{4}{ }^{+}$in Spring 2011 and for $\mathrm{NO}_{2}{ }^{-}+\mathrm{NO}_{3}{ }^{-}$in Spring 2010 and Summer 2010 (Figure 3). Regarding to $\mathrm{PO}_{4}{ }^{3-}$ daily fluxes, effluxes were only observed in summer, although in all seasons they were observed to be low, seasonal averages ranged between -8 and $6 \mu \mathrm{mol} \mathrm{m}^{-2} \mathrm{~d}^{-1}$ (Table 4). Si(OH) $)_{4}$ daily fluxes were positive in all seasons except summer where an influx of $93 \mu \mathrm{mol} \mathrm{m} \mathrm{m}^{-2} \mathrm{~d}^{-1}$ was calculated.

\section{Table 4}

Daily fluxes of oxygen and nutrients estimated for each season expressed in $\mu \mathrm{mol} \mathrm{m} \mathrm{m}^{-2} \mathrm{~d}^{-1}$. Annual averages are expressed in mmol m $\mathrm{m}^{-2}$.

\section{Discussion}

\subsection{Water column and sediment}

The similar values obtained for the different variables collected from different depths suggest a well-mixed water column in each sampling campaign. This is due to the shallow water column in the sampling station can be influenced by wave and currents. Therefore, any process or alteration happening on the surface could affect the 
bottom and vice versa. The water temperature varied between sampling campaigns depending on the annual pattern observed in the north-western Mediterranean with minimum temperatures reached during late winter and its maximum values about August (Puigserver et al., 2010; Mayer et al., 2012). This temperature pattern may have influenced DO variations throughout the year because temperature affects DO solubility. Regarding to $\mathrm{PO}_{4}{ }^{3-}$, Gadea et al. (2013) working on the same study area also detected the highest levels in summer. However, other authors observed minimum $\mathrm{PO}_{4}{ }^{3-}$ levels in late spring and during summer, such as Lucea et al. (2005), in the northwestern Mediterranean due to the influence of primary producers (Leblanc et al., 2003). All nutrient and WChl- $a$ values in the water column were similar to those measured by Gadea et al. (2013) and Sebastiá et al. (2013) and corresponded to levels found in other oligotrophic north-western Mediterranean areas (Lucea et al., 2005; Puigserver et al., 2010). Levels of potentially limiting nutrients to phytoplankton growth could be estimated using Redfield nutrient ratios and the criteria employed by Gadea et al. (2013). P was the most frequent limiting nutrient with $63 \%$ of the data set followed by Si $(13 \%)$ and $\mathrm{N}(9 \%)$. The remaining $13 \%$ was observed under balanced conditions. Gadea et al. (2013) and Sebastiá and Rodilla (2013) also detected P as the potential limiting nutrient in the coastal area around Gandia, especially in spring.

The uppermost sediment layer was under oxic conditions throughout the annual cycle, as can be seen from positive Eh values. Moreover, $\overline{\mathrm{I}}_{\mathrm{z}}$ was related inversely with SS $(\mathrm{r}=-0.66 ; p<0.01)$ and WChl- $a(\mathrm{r}=-0.64 ; p<0.01)$ due to water column particles absorbing and dispersing radiation. With regard to phytopigments, SChl- $a$ was always higher than Phaeo, which represents senescent and dead algal material. Therefore, pigments were mostly composed of active pigments. Different labile organic components such as PRT, CHO and BPC, can be used to assess trophic state in benthic systems from a biochemical approach (Dell'Anno et al., 2002). These compounds presented, basically, low values and were similar to those found in bottoms with similar characteristics in the Mediterranean Sea (Danovaro et al., 1998; Dell'Anno et al., 2002). BPC levels indicate that seven sampling campaigns presented oligotrophic conditions at the surface sediment. Only in Winter 2010 BPC levels were slightly higher than the threshold of $1000 \mu \mathrm{gC} \mathrm{g}{ }^{-1}$ between oligtrophic and mesotrophic ecosystems as determined by Dell'Anno et al. (2002) and Pusceddu et al. (2011).

The macrobenthic community was dominated by species sensitive to organic enrichment, the most abundant species belong to this ecological group (Borja et al., 2000) and Pinedo et al., in (GIG, 2008). In this sense, a negative statistical correlation was observed between species richness and labile organic fraction, BPC $(\mathrm{r}=-0.84$, 
$p<0.01)$ and silt and clay $(\mathrm{r}=-0.89, p<0.01)$. Despite being oligotrophic sediments, according to biochemical descriptors employed, even slight organic enrichment could play a key role in regulating the macrobenthic structure in this sublittoral bottom.

\subsection{Benthic fluxes}

DO fluxes in darkness represent benthic respiration (R) carried out by heterotrophic processes as respirating sediment community, organic mineralization carried out by microbial community and chemical oxidation. Some biochemical descriptors of sedimentary organic matter, such as BPC and CPE, correlated negatively with DO fluxes in darkness $(\mathrm{r}=-0.86, p<0.01$ with BPC; $\mathrm{r}=-0.91, p<0.01$ with $\mathrm{CPE})$, in spite of the very small fraction that BPC and CPE represent in OM content (2.7-13.1\% and $0.20-0.65 \%$ respectively). These observations support the idea by Arnosti and Holmer (2003), and Pastor et al. (2011), that a small organic fraction could be responsible for oxygen uptake in sediments. Furthermore, the relationship found between labile organic descriptors and benthic respiration could be more intense in oligotrophic conditions such as in the southernmost sector in the Gulf of Valencia. Heilskov et al. (2006) observed that mineralization rates did not respond equally to organic enrichment suggesting that poor sediments are highly sensitive to organic enrichment probably caused by carbon and nutrientlimited growth of microbial community. Other studies have also found that organic enrichment stimulates microbial activity in oligotrophic sediments (López et al., 1997; Holmer et al., 2003). In this study, we have observed that benthic respiration could be driven by quantitative changes in labile fraction of sedimentary organics throughout the year. However, Ní Longphuirt et al. (2007) and Ferrón et al. (2009a) observed in other coastal areas that benthic respiration was not related to temperature or total organic matter, notwithstanding changes in both these variables could induce alterations in heterotrophic processes (Hancke and Glud, 2004).

Oxygen light fluxes are more complex in areas where light reaches the seafloor due to the fact that both productive and degradation processes occurs simultaneously. In order to determine microphytobenthic and planktonic production inside benthic chambers the amount of chlorophyll $a$ from benthos and plankton inside the chambers were compared using SChl- $a$, bulk density of sediment, area of incubation, WChl- $a$ and incubated water volume. Basically, phytoplanktonic Chl- $a$ in incubated water was negligible $(0.2-0.6 \%$ in respect to total Chl- $a$ inside the chambers), so DO fluxes obtained from light chamber incubations were equivalent to net primary production carried out by microphytobenthos. A positive correlation between NPP and average irradiance incident at the 
sediment surface was observed $(\mathrm{r}=0.86, p<0.01)$. Thus, in both spring campaigns, in which incident irradiances were the highest, NPP were maximum. Therefore, DO fluxes were regulated by incident irradiance, stimulating photosynthetic rates in the microphytobenthic community. Nevertheless, other factors such as macrobenthic community, microbial community or organic matter quantity and quality also affected the net oxygen balance by varying degrees which resulted in high NPP in low irradiance conditions (e.g. Winter 2010), and low NPP rates in campaigns with medium/high $\overline{\mathrm{I}}_{\mathrm{z}}$ (e.g. Summer 2010).

R and NPP rates were used to apply the Trophic State Oxygen Index (TOSI, Viaroli et al., 1996) and to assess benthic metabolism. The sampling station was photoautotrophic throughout the year as seen in Figure 4: highly photoautotrophic during Spring 2010, Spring 2011 and Autumn 2011 campaigns and net photoautotrophic in the remaining campaigns. This index indicates that these well-sorted fine sands behaved as an autotrophic system throughout diurnal phase. The highest TOSI level was observed in both spring campaigns because of light patterns, and in Autumn 2011 low benthic respiration could have been responsible for the high levels of TOSI. In these autotrophic conditions, phototrophs produce an excess of organic matter and play the role of nutrient sink (Gazeau et al., 2005).

Fig.4. Trophic Oxygen State Index (TOSI; Viaroli et al., 1996) based on benthic respiration and benthic net primary production at sampling station in each campaign. TH: totally heterotrophic, NH: net heterotrophic, NA: net photoautotrophic, TA: highly photoautotrophic.

Compared with other coastal areas, benthic respiration in well-sorted fine sands is, in general, lower than those observed in more eutrophic ecosystems such as estuaries (Pratihary et al., 2009), coastal lagoons (Niencheski and Jahnke, 2002) or salt-marshes (Ferrón et al., 2009a). Even over sand bottoms in the Gulf of Valencia, in a very shallow station (Vidal et al., 1989) at a depth of $18 \mathrm{~m}$ (Morata et al., 2012) measured oxygen uptakes were higher in both places than in this study. NPP in this study (99 and $1197 \mu \mathrm{mol} \mathrm{m}^{-2} \mathrm{~h}^{-1}$ ) was within the range observed in other permeable bottoms by Marinelli et al. (1998) in the South Atlantic Bight (USA) at a depth of 20-40 m (-291 and $3065 \mu \mathrm{mol} \mathrm{m} \mathrm{m}^{-2} \mathrm{~h}^{-1}$ ) or Morata et al. (2012), although the latter presented slightly lower values, (-417 and 708 $\mu \mathrm{mol} \mathrm{m} \mathrm{m}^{-2} \mathrm{~h}^{-1}$ ). On the other hand, in areas with anthropic influence and river discharges such as in the Gulf of Trieste (Bertuzzi et al., 1997), NPP is not usually observed.

Regarding to nutrient fluxes, sediment behaved as a source of DIN in darkness during all sampling campaigns. Therefore, DIN producer processes were more important than potential sink reactions at the study site. These fluxes 
were mainly composed of ammonium as a result of organic matter mineralization, even though organic nitrogen mineralization could still produce nitrite and nitrate in oxic sediments and in the presence of chemolitotrophic bacteria, at least at the upper sediment layer. The maximum $\mathrm{PO}_{4}{ }^{3-}$ effluxes in darkness were observed in the warmest campaigns (Summer 2009 and Summer 2011) coinciding with low DO levels in water column, as also observed in the gulf of Cádiz (Spain) Ferrón et al. (2009b) and the lowest redox potential. This would indicate anoxic zones are nearer to surface sediment, where $\mathrm{P}$ release could take place. On the other hand, in this study a negative correlation between $\mathrm{PO}_{4}{ }^{3-}$ fluxes in dark chambers and mollusc density $(\mathrm{r}=-0.63, p<0.10)$ was observed. Probably, bioturbation generated by molluscs would have decreased $\mathrm{P}$ effluxes due to an increased oxygen exchange between sediment and water column and stimulating P sorption and coprecipitation (Mortimer et al., 1999). Si is required by some microalgae groups for instance, diatoms, silicoflagellates and other organisms such as radiolarian and foraminifera. Unlike other nutrients, $\mathrm{Si}$ mostly occurs as $\mathrm{Si}(\mathrm{OH})_{4}$ in the sea and is regenerated by dissolution (Ehrenhauss and Huettel, 2004). In this study, $\mathrm{Si}(\mathrm{OH})_{4}$ fluxes in darkness correlated positively with Phaeo in the sediment $(\mathrm{r}=0.64, p<0.10)$ suggesting that senescent or dead algal material, which is represented by phaeopigments, could cause Si biogenic dissolution.

With regard to light conditions, these kind of fluxes were observed to be statistically lower than in dark conditions for most nutrients according to Kruskall-Wallis test, for $\mathrm{NH}_{4}{ }^{+}(p=0.01), \mathrm{NO}_{2}{ }^{-}+\mathrm{NO}_{3}{ }^{-}(p<0.01), \mathrm{DIN}(p=0.01)$ and $\mathrm{Si}(\mathrm{OH})_{4}(p<0.01)$. These differences were due to microphytobenthos nutrient demand that involves nutrient fixation from water column and pore-water. Furthermore, $\mathrm{NO}_{2}{ }^{-}+\mathrm{NO}_{3}{ }^{-}$could be influenced by nitrification inhibition in light conditions (Guerrero and Jones, 1996; Herbert, 1999) involving higher $\mathrm{NO}_{2}{ }^{-}+\mathrm{NO}_{3}{ }^{-}$fluxes in darkness than in light. $\mathrm{Si}(\mathrm{OH})_{4}$ fluxes in light chambers correlated negatively with $\overline{\mathrm{I}}_{\mathrm{z}}(\mathrm{r}=-0.62, p<0.10)$ supporting the idea by Sigmon and Cahoon (1997) and Ní Longphuirt et al. (2009) in which light would stimulate $\mathrm{Si}(\mathrm{OH})_{4}$ fixation.

According to DO daily fluxes, the well-sorted fine sands behaved as autotrophic only during spring, influenced by high average incident irradiance, thereby leading to a lower DIN release from sediments because of microphytobenthic fixation. Annual metabolic cycle could be linked with light pattern owing to the strong correlation observed between DO daily fluxes and $\overline{\mathrm{I}}_{\mathrm{z}}(\mathrm{r}=0.98, p<0.01)$. Gazeau et al. (2005) also reported that bare sediments placed in shallow station in Palma Bay (Spain) only tended to have autotrophic conditions in the month of July. Another important factor that could regulate nutrient release in this biocenosis is macrobenthic community. $\mathrm{NO}_{2}{ }^{-}+\mathrm{NO}_{3}{ }^{-}$daily fluxes correlated with total macrofauna density $(\mathrm{r}=0.63, p<0.10)$ as this benthic organism can 
stimulate nitrification in several different ways. On the one hand, bioturbators change sediment properties by their activity in sediment affecting the redox conditions and increasing DO supply to deeper layers (Mermillod-Blondin and Rosenberg, 2006). On the other hand, in the lining of burrows generated by macrofauna and their faecal pellets there are favourable conditions for microbial activity and nitrification (Blackburn and Henriksen., 1983; Henriksen et al., 1983; Kristensen et al., 1985). In this sense, positive correlation was also detected between $\mathrm{Si}(\mathrm{OH})_{4}$ daily fluxes and total macrobenthic density $(\mathrm{r}=0.81, p<0.05)$. Suspension feeders and grazers feeding on diatoms probably produce an easily degradable material (faeces and pseudofaeces pellets ) that would enhance dissolution of biogenic silica, as observed by Bartoli et al. (2001) in sediments impacted by Tapes philipinarum farming in Sacca di Goro lagoon (Italy).

Annual benthic fluxes were estimated from daily fluxes in each season over the annual cycle (Table 4). This estimation implied that these bottoms are slightly heterotrophic over the annual cycle, with a DO uptake of -31 mmol m $\mathrm{m}^{-2} \mathrm{y}^{-1}$. Likewise, DIN and $\mathrm{Si}(\mathrm{OH})_{4}$ were released $\left(329\right.$ and $\left.68 \mathrm{mmol} \mathrm{m}^{-2} \mathrm{y}^{-1}\right)$ to water column. Nevertheless, P exchange between sediment-water interface was negligible. In order to explain and reduce the high number of variables to a lower number of unobserved latent variables, a factor analyses (FA) was performed. Variables with a very low measure of sampling adequacy were rejected so that FA was run using only 9 variables: $F_{D} D O, F_{D} D I N$, $\mathrm{F}_{\mathrm{D}} \mathrm{PO}_{4}{ }^{3-}$, silt and clay, $\overline{\mathrm{I}}_{\mathrm{z}}, \mathrm{Eh}, \mathrm{BPC}, \mathrm{CPE}$, and Phaeo. From this FA, three components were extracted with an eigenvalue above 1 that explained $78.6 \%$ of total variance. First of these axis represented $43.2 \%$ which was characterized by sedimentary biochemical compounds. This factor shows organic enrichment by BPC, CPE and Phaeo over fine sediments such as silt and clay. Therefore, higher levels of mud enhance organic matter stock, especially labile fraction. The second factor, that accounted for $23.1 \%$, related DO daily fluxes and $\overline{\mathrm{I}}_{\mathrm{z}}$ with DIN daily fluxes conversely. This factor provides evidence the influence of benthic primary production in the solute exchange between sediment and water. The third component (12.3\% of total variance) only linked negatively $\mathrm{PO}_{4}{ }^{3-}$ daily fluxes with redox potential representing P sorption onto sediment particles in oxic conditions (Table 5).

\section{Table 5}

Factor analysis results obtained from rotated component matrix applying principal components extraction method and varimax rotation method.

\subsection{Contribution of nutrient regeneration to benthic primary production}


Benthic nutrient regeneration placed in shallow bottoms can supply high percentages of nutrients required by primary producers. For that reason, the possible repercussions of benthic nutrient fluxes on benthic primary production were studied. For this purpose, it was assumed a null atmospheric nitrogen fixation by microalgae. GPP was expressed in carbon units applying photosynthetic quotient $\mathrm{O}_{2}: \mathrm{C}=1.2$ (Bartoli et al., 2012) in order to estimate theoretical N, P, and Si requirements by microphytobenthos (Table 6). Theoretical nutrient assimilations were obtained from the ratio $\mathrm{C}: \mathrm{N}=9$ as employed by Sundbäck et al. (2000) and Alsterberg et al. (2012) for microphytobenthos and from Redfield stoichiometric ratios $(\mathrm{C}: \mathrm{P}=106$ and $\mathrm{C}: \mathrm{Si}=6.6)$. To calculate benthic regeneration contribution to microphytobenthos, theoretical nutrient demand was compared to benthic nutrient fluxes in dark conditions. Table 6 shows that benthic fluxes could only supply more than $100 \%$ microphytobenthos $\mathrm{N}$ requirements in the autumn season. $\mathrm{P}$ and $\mathrm{Si}$ benthic fluxes were not sufficient to supply theoretical demand throughout the annual cycle. This implies that most of P and Si required by primary producers in the sediment must have come from the water column.

\section{Table 6}

Benthic primary production (GPP) expressed in $\mu \mathrm{mol} \mathrm{C} \mathrm{m}^{-2} \mathrm{~h}^{-1}$ and percent contribution of benthic dark fluxes to GPP.

In order to compare both benthic and planktonic primary production in this sampling site, planktonic production was calculated using integrated values of WChl- $a$ and applying the equation developed by Morán and Estrada (2006). These authors observed a close relationship between phytoplankton biomass and primary production working in the north-western Mediterranean Sea. The integrated values of WChl- $a$ ranged between 4.7 and $13.6 \mathrm{mg}$ $\mathrm{m}^{-2}$ which corresponded with a planktonic primary production of 426 and $632 \mathrm{mmol} \mathrm{C} \mathrm{m}^{-2} \mathrm{~d}^{-1}$ between the different seasons. If planktonic and benthic primary production are compared, primary production of the microphytobenthic community is the main source of organic matter in this coastal area. This benthic primary production represented between $51-78 \%$ of total primary production over the annual cycle. This pattern has also been reported by others authors in permeable sands inhabited by microphytobenthos such as Jahnke et al. (2000) in some summer campaigns in the Southern Atlantic Bight (USA) and Billerbeck et al. (2007) in incubations carried out in July in intertidal sandy bottoms located in the Wadden Sea. However, Gazeau et al. (2005), compiled data from shallow Mediterranean regions and estimated that microphytobenthic primary production only represents $35 \%$ of the total 
primary production for depths between $5-10 \mathrm{~m}$. All our results presented here provide information about benthic fluxes and primary production in calm sea conditions that allow researchers to work safely.

\section{Conclusions}

In this study, the entire benthic ecosystem has been taken into consideration (physics, chemical and biochemical variables, macrobenthic community, microphytobenthos) as well as water column variables, to achieve a complete understanding of the well-sorted fine sand ecosystem in the southernmost sector in the Gulf of Valencia. The use of a biochemical approach based on sedimentary organic descriptors (PRT, CHO, LIP and BPC) indicated oligotrophic conditions in these well-sorted fine sands. In this sense, the abundance of sensitive species to organic enrichment inhabiting this biocenosis supported this conclusion. Benthic respiration was driven by labile fraction of organic matter and phytopigments in spite of representing a very small fraction of total organic matter. Microphytobenthos play an important role in benthic metabolism influenced by annual light pattern. Only in the spring, when incident irradiance reached its maximum levels, these permeable sediments were able to release DO to the water column. Annually, as well as in the remaining seasons, sediments were heterotrophic consuming DO and releasing DIN and $\mathrm{Si}(\mathrm{OH})_{4}$ to the overlaying water. Throughout the annual cycle, microphytobenthos was the main primary producer in this coastal area located in the Gulf of Valencia and composed of well-sorted fine sands. Therefore, these bottoms have important implications for understanding nutrient regeneration and oxygen cycling in the near-shore ecosystem in this part of the Mediterranean.

\section{Acknowledgements}

We are grateful for the valuable comments of anonymous reviewers on previous version of the manuscript. This research was supported by the Conselleria d'Educació (Generalitat Valenciana).

\section{References}

Alsterberg, C., Sundbäck, K., Hulth, S., 2012. Functioning of a shallow-water sediment system during experimental warming and nutrient enrichment. Plos ONE. 7(12), e51503. http://dx.doi.org/10.1371/journal.pone.0051503.

Aminot, A., Chaussepied, M., 1983. Manuel des analyses chimiques en milieu marin. Centre National pour l'Explotation des Oceans, Brest, 395 pp.

APHA, AWWA, WEF, American Public Health, American Water Works Association, Water Environment Federation., 2012. Standard methods for the examination of water and wastewater $22^{\text {nd }}$ ed. American Public Health Association, Washington, 1360 pp. 
Arnosti, C., Holmer, M., 2003. Carbon cycling in a continental margin sediment: contrasts between organic matter characteristics and remineralization rates and pathways. Estuar. Coast. Shelf Sci. 58, 197-208. http://dx.doi.org/10.1016/S0272-7714(03)00077-5.

Barrón, C., Duarte, C.M., Frankignoulle, M., Borges, A.V. 2006. Organic carbon metabolism and carbonate dynamics in a mediterranean seagrass (Posidonia oceanica) meadow. Estuar. Coast. 29(3), 417-426. http://dx.doi.org/417-426. 10.1007/BF02784990.

Bartoli, M., Nizzoli, D., Viaroli, P., Turolla, E., 2001. Impact of Tapes philippinarum farming on nutrient dynamics and benthic in the Sacca di Goro. Hydrobiologia. 455, 203-212. http://dx.doi.org/10.1023/A:1011910422400

Bartoli, M., Castaldelli, G., Nizzoli, D., Viaroli, P., 2012. Benthic primary production and bacterial denitrification in a Mediterranean eutrophic coastal lagoon. J. Exp. Mar. Biol. Ecol. 438, 41-51. http://dx.doi.org/10.1016/j.jembe.2012.09.011.

Blackburn, T.H., Henriksen, K., 1983. Nitrogen cycling in different types of sediment from Danish waters. Limnol. Oceanogr. 28, 477-493.

Bellan-Santini, D., Lacaze, J.C., Poizat, C., 1994. Les biocénoses marines et littorals de Méditerranées, synthèse, menaces et perspectives. Patrimoines naturels, 19. Secrétariat de la faune et de la flore. MNHN, Paris, 246 pp.

Bertuzzi, A., Faganelli, J., Welker, C., Brambati, A., 1997. Benthic fluxes of dissolved inorganic carbon, nutrients and oxygen in the Gulf of Trieste (Northern Adriatic). Water Air Soil Pollut. 99 (1), 305-314. http://dx.doi.org/10.1023/A:1018398231038.

Billerbeck, M., Røy, H., Bosselmann, K., Huettel, M., 2007. Benthic photosynthesis in submerged Wadden Sea intertidal flats. Estuar. Coast. Shelf Sci. 71 (3-4), 704-716. http://dx.doi.org/10.1016/j.ecss.2006.09.019.

Borja, A., Franco, J., Pérez, V., 2000. A marine biotic index to establish the ecological quality of soft-bottom benthos within European estuarine and coastal environments. Mar. Pollut. Bull. 40, 1100-1114. http://dx.doi.org/10.1016/S0025-326X(00)00061-8.

Boudreau, B.P., Huettel, M., Forster, S., Jahnke, R.A., McLachlan, A., Middelburg, J.J., Nielsen, P., Sansone, F., Taghon, G., Van Raaphorst, W., Webster, I., Weslawski, J.M., Wiberg, P., Sundby, B., 2001. Permeable marine sediments: overturning an old paradigm. EOS. Trans. Am. Geophys. Union. 82, 133-136. http://dx.doi.org/10.1029/EO082i011p00133-01.

Castelli, A., Lardicci, C., Tagliapietra, D., 2004. Soft-bottom macrobenthos. In: Gambi M.C., Dappiano M. (Eds.) Mediterranean Marine Benthos: A Manual of methods for its sampling and study. Biologia Marina Mediterranea. Vol.11 (Suppl. 1), Genova. 99-131 pp.

Cloern, J.E., 2001. Our evolving conceptual model of the coastal eutrophication problem. Mar. Ecol. Prog. Ser. 210, 223-253. http://dx.doi.org/10.3354/meps210223.

Danovaro, R., Marrale, D., Della Croce, N., Dell'Anno, A., Fabiano., 1998. Heterotrophic nanoflagellates, bacteria, and labile organic compounds in continental shelf and deep-sea sediments of the Eastern Mediterranean. Microbial Ecol. 35, 244-255.

De-la-Ossa-Carretero, J.A., del-Pilar-Ruso, Y., Giménez-Casalduero, F., Sánchez-Lizaso, J.L., 2009. Testing BOPA index in sewage affected soft-bottom communities in the north-western Mediterranean. Mar. Pollut. Bull. 58(3), 332-340. http://dx.doi.org/10.1016/j.marpolbul.2008.10.017.

Dell'Anno, A., Mei, M.L., Pusceddu, A., Danovaro, R., 2002. Assessing the trophic state and eutrophication of coastal marine systems: a new approach base on the biochemical composition of sediment organic matter. Mar. Pollut. Bull. 44, 611-622. http://dx.doi.org/10.1016/S0025-326X(01)00302-2.

De Vittor, C., Faganelli, J., Emili, A., Covelli, S., Predonzani, S., Acquavita, A., 2012. Benthic fluxes of oxygen, carbon and nutrients in the Marano and Grado Lagoon (northern Adriatic Sea, Italy). Estuar. Coast. Shelf Sci. 113, 57-70. http://dx.doi.org/10.1016/j.ecss.2012.03.031.

Ehrenhauss, S., Huettel, M., 2004. Advective transport and decomposition of chain-forming planktonic diatoms in permeable sediments. J. Sea. Res. 52, 179-197. http://dx.doi.org/10.1016/j.seares.2004.01.004. 
Ferrón. S., Ortega, T., Forja, J.M., 2009a. Benthic fluxes in a tidal salt marsh creek affected by fish farm activities: Río San Pedro (Bay of Cadiz, SW Spain). Mar. Chem. 113 (1-2), 50-62. http://dx.doi.org/10.1016/j.marchem.2008.12.002.

Ferrón, S., Alonso-Pérez, F., Anfuso, E., Murillo, F.J., Ortega, T., Castro, C.G., Forja, J.M., 2009b. Benthic nutrient recycling in the Northeastern shelf of the Gulf of Cádiz (SW Iberian Peninsula). Mar. Ecol. Prog. Ser. 390, 79-95. http://dx.doi.org/10.3354/meps08199.

Fichez, R., 1991. Composition and fate of organic matter in submarine cave sediments; implications for the biogeochemical cycle of organic carbon. Oceanol. Acta. 14, 369-377.

Freitas, U., Niencheski, L.F.H., Zarzur, S., Manzolli, R.P., Vieira, J.P.P., Rosa, L.C., 2008. Influência de um cultivo de camarão sobre o metabolismo bêntico e a qualidade da água. Rev. Bras. Eng. Agríc. Ambient. 12(3), 293-301. http://dx.doi.org/10.1590/S1415-43662008000300011.

Gadea, I., Rodilla, M., Sospedra, J., Falco, S., Morata, T., 2013. Seasonal dynamics of the phytoplankton community in the Gandia coastal area, Southern Gulf of Valencia. Thalassas. 29(1), 37-60.

Gattuso, J.-P., Gentili, B., Duarte, C. M., Kleypas, J. A., Middelburg, J. J., and Antoine, D., 2006. Light availability in the coastal ocean: impact on the distribution of benthic photosynthetic organisms and their contribution to primary production, Biogeosciences, 3, 489-513. http://dx.doi.org/10.5194/bg-3-489-2006.

Gazeau, F., Duarte, C.M., Gattuso, J.-P., Barrón, C., Navarro, N., Prairie, Y.T., Calleja, M., Delille, B., Frankingnoulle, M., Borges, A.V., 2005. Whole-system metabolism and $\mathrm{CO}_{2}$ fluxes in a Mediterranean Bay dominated by seagrass beds (Palma Bay, NW Mediterranean). Biogeosciences. 2, 43-60. http://dx.doi.org/10.5194/bg-2-43-2005.

GIG. 2008. WFD Intercalibration technical report for coastal and transitional waters in the Mediterranean ecoregion. In: WFD Intercalibration Technical report-Part 3: Coastal and Transitional Waters. Available at: http://publications.jrc.ec.europa.eu/repository/bitstream/111111111/10473/1/3010_08-volumecoast.pdf [30/09/2014].

Guerrero, M.A., Jones, R.D., 1996. Photoinhibition of marine nitrifying bacteria. I. Wavelength-dependent response. Mar. Ecol. Progr. Ser. 141, 183-192.

Hall, S.J., 2002. The continental shelf benthic ecosystem: current status, agents for change and future prospects. Environ. Conserv. 29: 350-374. http://dx.doi.org/10.1017/S0376892902000243.

Hancke, K., Glud, R., 2004. Temperature effects on respiration and photosynthesis in three diatom-dominated benthic communities. Aquat. Microb. Ecol. 37, 265-281. http://dx.doi.org/10.3354/ame037265.

Heilskov, A.C., Alperin, M., Holmer, M., 2006. Benthic fauna bio-irrigation effects on nutrient regeneration in fish farm sediments. J. Exp. Mar. Biol. Ecol. 339: 204-225. http://dx.doi.org/10.1016/j.jembe.2006.08.003.

Henriksen, K., Rasmussen, M.B., Jensen, A., 1983. Effect of bioturbation on microbial nitrogen transformations in the sediment and fluxes of ammonium and nitrate to the overlaying water. Ecol. Bull. 35, 193-205.

Herbert, R.A., 1999. Nitrogen cycling in coastal marine ecosystems. FEMS Microbiol. Rev. 23, 563-590.

Holmer, M., Duarte, C.M., Marbá, N., 2003. Sulfur cycling and seagrass (Posidonia oceanica) status in carbonate sediments. Biogeochemistry. 66, 223-239. http://dx.doi.org/10.1023/B:BIOG.0000005326.35071.51.

Huettel, M., Berg, P., Kostka, J.E., 2014. Benthic exchange and biogeochemical cycling in permeable sediments. Annu. Rev. Mar. Sci. 6, 23-51. http://dx.doi.org/10.1146/annurev-marine-051413-012706.

Jahnke, R.A., Nelson, J.R., Marinelli, R.L., Eckman, J.E., 2000. Benthic flux of biogenic elements on the Southeastern US continental shelf: influence of pore water advective transport and benthic microalgae. Cont. Shelf Res. 20, 109-127. http://dx.doi.org/10.1016/S0278-4343(99)00063-1.

Jahnke, R., Richards, M., Nelson, J., Robertson, C., Rao, A., Jahnke, D., 2005. Organic matter remineralization and porewater exchange rates in permeable South Atlantic Bight continental shelf sediments. Cont. Shelf Res. 25, 1433-1452. http://dx.doi.org/10.1016/j.csr.2005.04.002. 
Jahnke, R.A., Nelson, J.R., Richards, M.E., Robertson, C.Y., Rao, A.M., Jahnke, D.B., 2008. Benthic primary productivity on the Georgia midcontinental shelf: benthic flux measurements and high-resolution continuous in situ PAR records. J. Geophys. Res. 113. C08022. http://dx.doi.org/10.1029/2008JC004745.

Jahnke, R.A., 2010. Global synthesis. In: Liu, K.-K., Atkinson, L., Quiñones, R., Talaue-McManus, L. (Eds.), Carbon and nutrient fluxes in continental margins: a global synthesis. Springer, Berlin, pp. 597-615.

Jørgensen, B.B., 2006. Bacteria and marine biogeochemistry. In: Schulz, H.D., Zabel, M. (Eds.), Marine geochemistry. Springer-Verlag, Berlín, pp. 169-206.

Karydis, M., Kitsiou, D., 2012. Eutrophication and environmental policy in the Mediterranean Sea: a review. Environ. Monit. Assess. 184, 4931-4984.

Kristensen, E., Jensen, M.H., Andersen, T.K., 1985. The impact of polychaete (Nereis virens Sars) burrows on nitrification and nitrate reduction in estuarine sediments. J. Exp. Mar. Biol. Ecol. 85, 75-91.

Leblanc, K., Quéguiner, B., Garcia, N., Rimmelin, P., Raimbault, P., 2003. Silicon cycle in the NW Mediterranean Sea: seasonal study of coastal oligotrophic site. Oceanol. Acta. 26, 339-355. http://dx.doi.org/10.1016/S03991784(03)00035-5.

Loassachan, N., Ichimi, K. and Tada, K., 2009. Evidence of microphytobenthic roles on coastal shallow water of the Seto Inland Sea, Japan. J. Oceanogr. 65, 361-372. http://dx.doi.org/10.1007/s10872-009-0033-9.

López, N.I., Duarte, C.M., Vallespinós, F., Romero, J., Alcoverro, T., 1997. The effect of nutrient additions on bacterial activity in seagrass (Posidonia oceanica) sediments. J. Exp. Mar. Biol. Ecol. 224: 155-165. http://dx.doi.org/10.1016/S0022-0981(97)00189-5.

Lorenti, M., De Falco, G., 2004. Measurements and characterization of abiotic variables. In: Gambi M.C., Dappiano M. (Eds.), Mediterranean Marine benthos: a manual of methods for its sampling and study. Vol.11 (Suppl. 1), Genova, 1-37 pp.

Lucea, A., Duarte, C.M., Agustí, S., Kennedy, H., 2005. Nutrient dynamics and ecosystem metabolism in the Bay of Blanes (NW Mediterranean). Biogeochemistry. 73, 303-323. http://dx.doi.org/10.1007/s10533-004-0059-4.

MAGRAMA, Ministerio de Agricultura, Alimentación y Medio Ambiente., 2010. Estudios ecocartográficos del litoral. http://www.ecocartografias.com. [4-11-2013].

Marinelli, R.L., Jahnke, R.A., Craven, D.B., Nelson, J.R., Eckman, J.E., 1998. Sediment nutrient dynamics on the South Atlantinc Bight continental shelf. Limnol. Oceanogr. 43(6), 1305-1320.

Mayer, P., Estruch, V.D., Jover, M., 2012. A two-stage growth model for gilthead sea bream (Sparus aurata) based on the thermal growth coefficient. Aquaculture. 358-359, 6-13. http://dx.doi.org/10.1016/j.aquaculture.2012.06.016.

Mermillod-Blondin, F., Rosenberg, R., 2006. Ecosystem engineering: the impact of bioturbation on biogeochemical processes in marine and freshwater benthic habitats. Aquat. Sci. 68, 434-442. http://dx.doi.org/10.1007/s00027-006-0858-x.

Mermillod-Blondin, F., Lemoine, D., Boisson, J.-C., Malet, E., Montuelle, B., 2008. Relative influences of submersed macrophytes and bioturbating fauna on biogeochemical processes and microbial activities in freshwaters sediments. Freshw. Biol. 53, 1969-1982. http://dx.doi.org/10.1111/j.1365-2427.2008.02020.x.

Morán, X.A.G., Estrada, M., 2005. Winter pelagic photosynthesis in the NW Mediterranean. Deep-Sea Res. I. 52, 1806-1822. http://dx.doi.org/10.1016/j.dsr.2005.05.009.

Morata, T., Sospedra, J., Falco, S., Rodilla, M., 2012. Exchange of nutrients and oxygen across the sediment-water interface below a Sparus aurata marine fish farm in the north-western Mediterranean Sea. J. Soil. Sediment. 12(10), 1623-1632. http://dx.doi.org/10.1007/s11368-012-0581-2.

Morata, T., Falco, S., Sospedra, J., Gadea, I., Rodilla, M., 2014. Benthic recovery after the cessation of a gilt-head seabream, Sparus aurata, farm in the Mediterranean Sea. J. World Aquacult. Soc. 45(4), 380-391. http://dx.doi.org/10.1111/jwas.12128. 
Mortimer, R.J.G., Davey, J.T., Krom, M.D., Watson, P.G., Frickers, P.E., Clifton, R.J. 1999. The effect of macrofauna on porewater profiles and nutrient fluxes in the intertidal zone of the Humber Estuary. Estuar. Coast. Shelf Sci.48, 683-699. http://dx.doi.org/10.1006/ecss.1999.0479.

Niencheski, L.F., Jahnke, R.A., 2002. Benthic respiration and inorganic nutrient fluxes in the Estuary Region of Patos Lagoon (Brazil). Aquat. Geochem. 8 (3), 135-152. http://dx.doi.org/10.1023/A:1024207220266.

Ní Longphuirt, S., Clavier, J., Grall, J., Chauvad, L., Le Loc'h, F., Le Berre, I., Flye-Sainte-Marie, J., Richard, J., Leynaert, A., 2007. Primary production and spatial distribution of subtidal microphytobenthos in a temperate coastal system, the Bay of Brest, France. Estuar. Coast. Shelf Sci. 74, 367-380. http://dx.doi.org/10.1016/j.ecss.2007.04.025.

Ní Longphuirt, S., Ragueneau, O., Chauvaud, L., Martin, S., Jean, F., Thouzeau, G., Leynaert, A., 2009. Diurnal heterogeneity in silicic acid fluxes in shallow coastal sites: causes and implications. Estuar. Coast. Shelf Sci. 82, 495-502. http://dx.doi.org/10.1016/j.ecss.2009.02.014.

Nizzoli, D., Bartoli, M., Viaroli, P., 2007. Oxygen and ammonium dynamics during a farming cycle of the bivalve Tapes philippinarum. Hydrobiologia. 587, 25-36. http://dx.doi.org/10.1007/s10750-007-0683-9.

Nozais, C., Perissinotto, R., Tita, G., 2005. Seasonal dynamics of meiofauna in a South African temporarily open/closed estuary (Mdloti Estuary, Indian Ocean). Estuar. Coast. Shelf Sci. 62, 325-338. http://dx.doi.org/10.1016/j.ecss.2004.09.020.

Pastor, L., Deflandre, B., Viollier, E., Cathalot, C., Metzger, E., Rabouille, C., Escoubeyrou, K., Lloret, E., Pruski, A.M., Vétion, G., Desmalades, M., Buscail, R., Grémare, A., 2011. Influence of the organic matter composition on benthic oxygen demand in the Rhône River prodelta (NW Mediterranean Sea). Cont. Shelf Res. 31, 10081019. http://dx.doi.org/10.1016/j.csr.2011.03.007.

Perissinotto, R., Nozais, C., Kibirige, I., 2002. Spatio-temporal dynamics of phytoplankton and microphytobenthos in a South African temporaly-open estuary. Estuar. Coast. Shelf Sci. 55: 47-58. DOI: 10.1006/ecss.2001.0885.

Pratihary, A.K., Naqvi, S.W.A., Naik, H., Thorat, B.R., Narvenkar, G., Manjunatha, B.R., Rao, V.P., 2009. Benthic fluxes in a tropical Estuary and their role in the ecosystem. Estuar. Coast. Shelf Sci. 85, 387-398. http://dx.doi.org/10.1016/j.ecss.2009.08.012.

Puigserver, M., Monerris, N., Pablo, P., Alós, J., Moyà, G., 2010. Abundance patterns of the toxic phytoplankton in coastal waters of the Balearic Archipelago (NW Mediterranean Sea): a multivariate approach. Hydrobiologia. 644, 145-157. http://dx.doi.org/10.1007/s10750-010-0107-0.

Pusceddu, A., Dell'Anno, A., Fabiano, M., Danovaro, R., 2004. Quantity and biochemical composition of organic matter in marine sediments. In: Gambi M.C., Dappiano M. (Eds.), Mediterranean Marine Benthos: A Manual of methods for its sampling and study. Biologia Marina Mediterranea. Vol.11 (Suppl. 1), Genova, 39-53 pp.

Pusceddu, A., Bianchelli, S., Gambi, C., Danovaro, R., 2011. Assesment of benthic trophic status of marine coastal ecosystems: significance of meiofaunal rare taxa. Estuar. Coast. Shelf Sci. 93, 420-430. http://dx.doi.org/10.1016/j.ecss.2011.05.012.

Sarker, MD.J., Yamamoto, T. and Hashimoto, T., (2009). Contribution of benthic microalgae to the whole water algal biomass and primary production in Suo Nada, the Seto Inland Sea, Japan. J. Oceanogr. 65, 311-323. http://dx.doi.org/10.1111/j.1365-2427.2008.02020.x.

Sebastiá, M.T., Rodilla, M., 2013. Nutrient and phytoplankton analysis of a Mediterranean coastal area. Environ. Manage. 51, 225-240. http://dx.doi.org/10.1007/s00267-012-9986-3.

Sebastiá, M.-T., Rodilla, M., Falco, S., Sanchis, J.-A., 2013. Analysis of the effects of wet and dry seasons on a Mediterranean river basin: consequences for coastal waters and its quality management. Ocean. Coast. Manage. 78, 45-55. http://dx.doi.org/10.1016/j.ocecoaman.2013.03.012.

Sigmon, D.E., Cahoon, L.B., 1997. Comparative effects of benthic microalgae and phytoplankton on dissolved silica fluxes. Aquat. Microb. Ecol. 13, 275-284. http://dx.doi.org/10.3354/ame013275.

Shepard, F.P., 1954. Nomenclature based on sand-silt-clay relations. J. Sediment. Petrol. 24: 151-158. 
Smayda, T.J., 2005. Eutrophication and phytoplankton. In: Wassmann, P., Olli, K. (Eds.), Drainage basin nutrient inputs and eutrophication: an integrated approach. University of Tromsø, pp 89-98.

Smith, V.H., 2002. Eutrophication of freshwater and coastal marine ecosystems. A global problem. Environ. Sci. Pollut. R. 10(2), 126-139. http://dx.doi.org/10.1065/espr2002.12.142.

Sundbäck, K., Miles, A., Göransson, E., 2000. Nitrogen fluxes, denitrification and the role of 22icrophytobenthos in microtidal shallow-water sediments: an annual study. Mar. Ecol. Prog. Ser. 200, 59-76. http://dx.doi.org/10.3354/meps200059.

Viaroli, P., Bartoli, M., Bondavalli, C., Christian, R.R., 1996. Macrophyte communities and their impact on benthic fluxes of oxygen, sulphide and nutrients in shallow eutrophic environments. Hydrobiologia. 329, 105-119. http://dx.doi.org/10.1007/BF00034551.

Vidal, M., Romero, J., Camp, J., 1989. Sediment-water nutrient fluxes: preliminary results of in situ measurements in Alfaques Bay, Ebro River Delta. Sci. Mar. 53(2-3), 505-511. 


\section{Artwork and Tables with Captions}

( 2 column fitting)

\section{Table 1}

Averages and ranges of variables measured in water column in each sampling campaign.

\begin{tabular}{|c|c|c|c|c|c|c|c|c|c|c|}
\hline & $\begin{array}{l}\mathrm{T} \\
{ }^{\circ} \mathrm{C}\end{array}$ & $\begin{array}{c}\text { SS } \\
\mathrm{mg} \mathrm{l}^{-1}\end{array}$ & $\begin{array}{l}\text { DO } \\
\mu \mathrm{M}\end{array}$ & $\begin{array}{c}\mathbf{N H}_{4}^{+} \\
\mu \mathrm{M}\end{array}$ & $\begin{array}{c}\mathrm{NO}_{2}^{-} \\
+\mathrm{NO}_{3}^{-} \\
\mu \mathrm{M}\end{array}$ & $\begin{array}{c}\text { DIN } \\
\mu \mathrm{M}\end{array}$ & $\begin{array}{c}\mathbf{P O}_{4}{ }^{3-} \\
\mu \mathrm{M}\end{array}$ & $\begin{array}{l}\mathbf{T P} \\
\mu \mathrm{M}\end{array}$ & $\begin{array}{c}\mathrm{Si}(\mathbf{O H})_{4} \\
\mu \mathrm{M}\end{array}$ & $\begin{array}{c}\text { WChl-a } \\
\mu \mathrm{g} \mathrm{l}^{-1}\end{array}$ \\
\hline \multirow{2}{*}{$\begin{array}{l}\text { Summer } \\
2009\end{array}$} & 26.9 & 10 & 222 & 0.1 & 1.0 & 1.1 & 0.15 & - & 2.9 & 1.91 \\
\hline & $26.5-27.0$ & $8-12$ & $219-231$ & $<0.1-0.5$ & $<0.1-1.5$ & $<0.1-2.0$ & $0.13-0.17$ & - & $2.2-3.9$ & $1.33-2.71$ \\
\hline \multirow{2}{*}{$\begin{array}{l}\text { Winter } \\
2010\end{array}$} & 11.5 & 13 & 287 & 0.3 & 3.6 & 3.9 & 0.10 & 0.26 & 3.3 & 1.67 \\
\hline & $11.1-11.7$ & $12-14$ & $286-288$ & $<0.1-0.8$ & $2.9-4.0$ & $3.1-4.3$ & $0.04-0.14$ & $0.16-0.32$ & $3.2-3.4$ & $1.35-1.91$ \\
\hline \multirow{2}{*}{$\begin{array}{l}\text { Spring } \\
2010\end{array}$} & 20.5 & 9 & 241 & 1.6 & 5.8 & 7.4 & 0.05 & 0.20 & 2.0 & 0.61 \\
\hline & $20.2-20.7$ & $9-10$ & $238-245$ & $0.8-3.0$ & $<0.1-11.6$ & $3.0-12.4$ & $0.03-0.06$ & $0.16-0.21$ & $1.7-2.3$ & $0.46-0.94$ \\
\hline \multirow{2}{*}{$\begin{array}{l}\text { Summer } \\
2010\end{array}$} & 25.0 & 11 & 245 & 1.1 & 2.0 & 3.1 & 0.09 & 0.13 & 1.8 & 0.63 \\
\hline & $24.8-25.1$ & $10-12$ & $243-246$ & $0.8-1.9$ & $<0.1-7.1$ & $0.8-8.0$ & $0.08-0.11$ & $0.11-0.14$ & $1.5-2.0$ & $0.57-0.67$ \\
\hline \multirow{2}{*}{$\begin{array}{l}\text { Spring } \\
2011\end{array}$} & 23.1 & 7 & 228 & $<0.1$ & 2.9 & 2.9 & 0.03 & 0.12 & 1.7 & 0.45 \\
\hline & $23.0-23.1$ & $4-11$ & $225-231$ & $<0.1-0.1$ & $1.6-4.9$ & $1.6-5.0$ & $0.01-0.05$ & $0.11-0.13$ & $1.1-2.6$ & $0.33-0.54$ \\
\hline \multirow{2}{*}{$\begin{array}{l}\text { Summer } \\
2011\end{array}$} & 26.6 & 8 & 230 & 0.3 & 1.4 & 1.7 & 0.04 & 0.13 & 1.7 & 0.60 \\
\hline & $26.6-26.6$ & $6-8$ & $229-231$ & $0.2-0.4$ & $0.6-2.4$ & $1.0-2.6$ & $0.01-0.08$ & $0.09-0.16$ & $1.4-2.1$ & $0.53-0.67$ \\
\hline \multirow{2}{*}{$\begin{array}{l}\text { Autumn } \\
2011\end{array}$} & 16.4 & 8 & 263 & 0.5 & 2.0 & 2.5 & 0.04 & 0.16 & 2.4 & 0.80 \\
\hline & $16.1-16.6$ & $6-9$ & $262-265$ & $0.4-0.6$ & $1.5-2.5$ & $1.9-3.0$ & $0.03-0.04$ & $0.13-0.22$ & $2.1-2.7$ & $0.67-0.99$ \\
\hline \multirow{2}{*}{$\begin{array}{l}\text { Winter } \\
2012\end{array}$} & 14.4 & 13 & 305 & 0.2 & 0.6 & 0.8 & 0.05 & 0.24 & 0.2 & 1.36 \\
\hline & $14.3-14.4$ & $12-14$ & $303-306$ & $<0.1-0.3$ & $0.5-0.7$ & $0.5-1.0$ & $0.04-0.08$ & $0.17-0.36$ & $0.1-0.3$ & $0.93-1.69$ \\
\hline
\end{tabular}


( 1.5 column fitting)

\section{Table 2}

Physico-chemical characteristics of surface sediment for each campaign.

\begin{tabular}{lccccc}
\hline & $\overline{\mathbf{I}}_{\mathbf{z}}$ & $\mathbf{E h}$ & $\mathbf{D}_{\mathbf{5 0}}$ & $\begin{array}{c}\text { Very Fine and } \\
\text { Fine Sand } \\
0.063-25 \mathrm{~mm}\end{array}$ & $\begin{array}{c}\text { Silt and Clay } \\
<0.063 \mathrm{~mm}\end{array}$ \\
& $\mathrm{~W} \mathrm{~m}{ }^{-2}$ & $\mathrm{mV}$ & $\mathrm{mm}$ & $\%$ & $\%$ \\
\hline $\begin{array}{l}\text { Summer } \\
\mathbf{2 0 0 9}\end{array}$ & 31.1 & $13 \pm 32$ & 0.128 & 94.5 & 4.0 \\
$\begin{array}{l}\text { Winter } \\
\mathbf{2 0 1 0}\end{array}$ & 14.4 & $108 \pm 27$ & 0.152 & 88.8 & 4.1 \\
$\begin{array}{l}\text { Spring } \\
\mathbf{2 0 1 0}\end{array}$ & 78.3 & $45 \pm 34$ & 0.151 & 89.7 & 3.3 \\
\hline $\begin{array}{l}\text { Summer } \\
\mathbf{2 0 1 0}\end{array}$ & 19.2 & $90 \pm 25$ & 0.147 & 93.1 & 2.3 \\
$\begin{array}{l}\text { Spring } \\
\mathbf{2 0 1 1}\end{array}$ & 71.3 & $59 \pm 21$ & 0.150 & 94.3 & 3.1 \\
\hline $\begin{array}{l}\text { Summer } \\
\mathbf{2 0 1 1}\end{array}$ & 31.3 & $40 \pm 29$ & 0.152 & 92.4 & 4.5 \\
$\begin{array}{l}\text { Autumn } \\
\mathbf{2 0 1 1}\end{array}$ & 26.2 & $120 \pm 55$ & 0.120 & 91.6 & 2.4 \\
\hline $\begin{array}{l}\text { Winter } \\
\mathbf{2 0 1 2}\end{array}$ & 9.3 & $112 \pm 20$ & 0.131 & 94.9 & \\
\hline
\end{tabular}


( 1.5 column fitting)

Table 3

Biochemical variables and standard deviation measured at the superficial sediment layer in each sampling campaign.

\begin{tabular}{|c|c|c|c|c|c|c|c|c|}
\hline & $\mathbf{O M}$ & SChl-a & Phaeo & CPE & PRT & CHO & LIP & BPC \\
\hline & $\%$ & $\mu \mathrm{g} \mathrm{g}^{-1}$ & $\mu \mathrm{g} \mathrm{g}^{-1}$ & $\mu \mathrm{g} \mathrm{g}^{-1}$ & $\mu \mathrm{g} \mathrm{g}^{-1}$ & $\mu \mathrm{g} \mathrm{g}^{-1}$ & $\mu \mathrm{g} \mathrm{g}^{-1}$ & $\mu \mathrm{gC} \mathrm{g}^{-1}$ \\
\hline $\begin{array}{l}\text { Summer } \\
2009\end{array}$ & $0.95 \pm 0.25$ & $2.89 \pm 0.02$ & $0.47 \pm 0.06$ & 3.36 & $579 \pm 55$ & $584 \pm 195$ & $256 \pm 110$ & 709 \\
\hline $\begin{array}{l}\text { Winter } \\
2010\end{array}$ & $1.10 \pm 0.31$ & $2.65 \pm 0.78$ & $1.19 \pm 0.69$ & 3.84 & $744 \pm 384$ & $702 \pm 52$ & $123 \pm 52$ & 738 \\
\hline $\begin{array}{l}\text { Spring } \\
2010\end{array}$ & $1.23 \pm 0.24$ & $2.83 \pm 0.61$ & $1.93 \pm 0.44$ & 4.76 & $530 \pm 64$ & $325 \pm 58$ & $1113 \pm 712$ & 1224 \\
\hline $\begin{array}{l}\text { Summer } \\
2010\end{array}$ & $1.40 \pm 0.57$ & $2.37 \pm 0.41$ & $0.74 \pm 0.20$ & 3.11 & $396 \pm 104$ & $315 \pm 39$ & $248 \pm 200$ & 506 \\
\hline $\begin{array}{l}\text { Spring } \\
2011\end{array}$ & $0.89 \pm 0.20$ & $1.88 \pm 0.30$ & $0.64 \pm 0.11$ & 2.52 & $392 \pm 45$ & $401 \pm 55$ & $302 \pm 87$ & 579 \\
\hline $\begin{array}{l}\text { Summer } \\
2011\end{array}$ & $0.52 \pm 0.00$ & $2.87 \pm 0.93$ & $0.50 \pm 0.14$ & 3.37 & $732 \pm 92$ & $296 \pm 42$ & $272 \pm 93$ & 681 \\
\hline $\begin{array}{l}\text { Autumn } \\
2011\end{array}$ & $1.14 \pm 0.00$ & $1.81 \pm 0.19$ & $0.45 \pm 0.23$ & 2.26 & $473 \pm 62$ & $330 \pm 45$ & $136 \pm 18$ & 466 \\
\hline $\begin{array}{l}\text { Winter } \\
2012\end{array}$ & $1.23 \pm 0.74$ & $2.78 \pm 0.25$ & $0.47 \pm 0.14$ & 3.25 & $160 \pm 29$ & $415 \pm 70$ & $110 \pm 17$ & 327 \\
\hline
\end{tabular}

\section{( 1.5 column fitting)}

\section{Table 4}

Daily fluxes of oxygen and nutrients estimated for each season expressed in $\mu \mathrm{mol} \mathrm{m} \mathrm{m}^{-2} \mathrm{~d}^{-1}$. Annual averages are expressed in $\mathrm{mmol} \mathrm{m} \mathrm{y}^{-2}$.

\begin{tabular}{lcccccc}
\hline & $\begin{array}{c}\mathbf{F}_{\mathbf{D}} \\
\mathbf{D O}\end{array}$ & $\begin{array}{c}\mathbf{F}_{\mathbf{D}} \\
\mathbf{N H}_{4}{ }^{+}\end{array}$ & $\begin{array}{c}\mathbf{F}_{\mathbf{D}} \\
\mathbf{N O}_{2}{ }^{-}+\mathbf{N O}_{\mathbf{3}^{-}}\end{array}$ & $\begin{array}{c}\mathbf{F}_{\mathbf{D}} \\
\mathbf{D I N}\end{array}$ & $\begin{array}{c}\mathbf{F}_{\mathbf{D}} \\
\mathbf{P O}_{4}{ }^{{ }^{-}}\end{array}$ & $\begin{array}{c}\mathbf{F}_{\mathbf{D}} \\
\mathbf{S i}(\mathbf{O H})_{\mathbf{4}}\end{array}$ \\
\hline Winter & -4956 & 584 & 404 & 988 & -8 & 685 \\
Spring & 6966 & 100 & 64 & 164 & -6 & 5 \\
Summer & -1168 & 502 & 47 & 548 & 6 & -93 \\
\hline Autumn & -1184 & 1632 & 279 & 1911 & -3 & 153 \\
\hline Annual & $\mathbf{- 3 1}$ & $\mathbf{2 5 7}$ & $\mathbf{7 2}$ & $\mathbf{3 2 9}$ & $\mathbf{- 1}$ & $\mathbf{6 8}$ \\
\hline
\end{tabular}


(Single column fitting)

\section{Table 5}

Factor analysis results obtained from rotated component matrix applying principal components extraction method and varimax rotation method.

\begin{tabular}{lrrr}
\hline & $\mathbf{1}$ & $\mathbf{2}$ & $\mathbf{3}$ \\
\hline F $_{\text {D DO }}$ & 0.310 & 0.573 & 0.008 \\
F $_{\text {D PO4 }}{ }^{3-}$ & -0.185 & -0.071 & 0.913 \\
F $_{\text {DID }}$ & 0.134 & -0.834 & -0.022 \\
\hline$\overline{\mathbf{I}}_{\mathbf{z}}$ & 0.358 & 0.786 & 0.068 \\
\hline Eh & -0.248 & -0.561 & -0.662 \\
\hline BPC & 0.904 & 0.395 & 0.120 \\
Phaeo & 0.859 & 0.320 & -0.279 \\
\hline CPE & 0.813 & 0.219 & 0.062 \\
Silt\&Clay & 0.829 & -0.415 & -0.139 \\
\hline
\end{tabular}

(Single column fitting)

\section{Table 6}

Benthic primary production (GPP) expressed in $\mu \mathrm{mol} \mathrm{C} \mathrm{m}^{-2} \mathrm{~h}^{-1}$ and percent contribution of benthic dark fluxes to GPP.

\begin{tabular}{l|cccc}
\hline & GPP & \% N & \% P & \% Si \\
\hline Winter & 961 & 42 & - & 27 \\
Spring & 1553 & 4 & - & 7 \\
Summer & 981 & 42 & 6 & 11 \\
Atumn & 509 & 194 & - & 14 \\
\hline
\end{tabular}




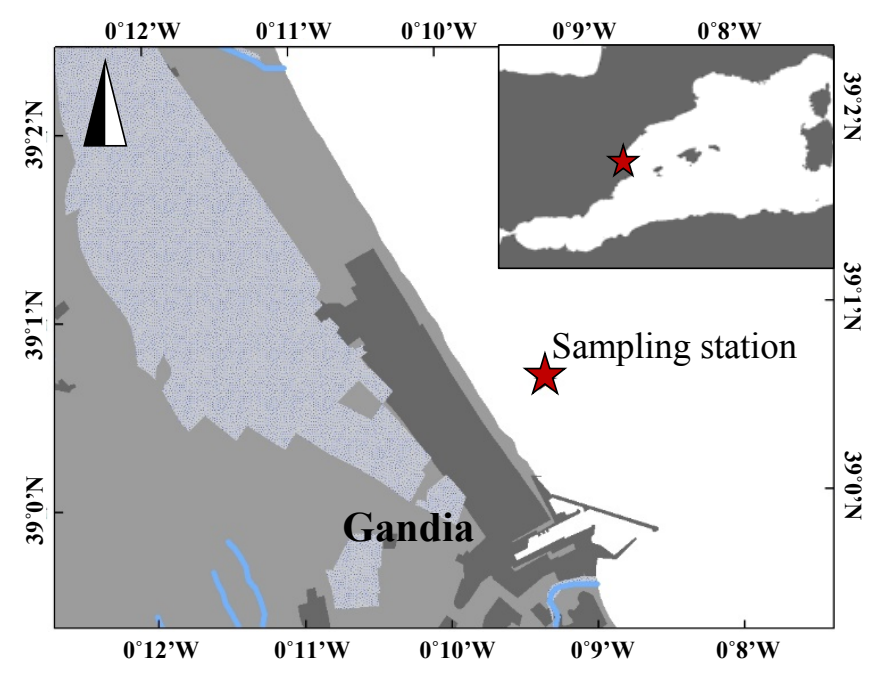

Fig. 1. Sampling site at the southernmost sector of the Gulf of Valencia (Western Mediterranean). (Single column fitting image)
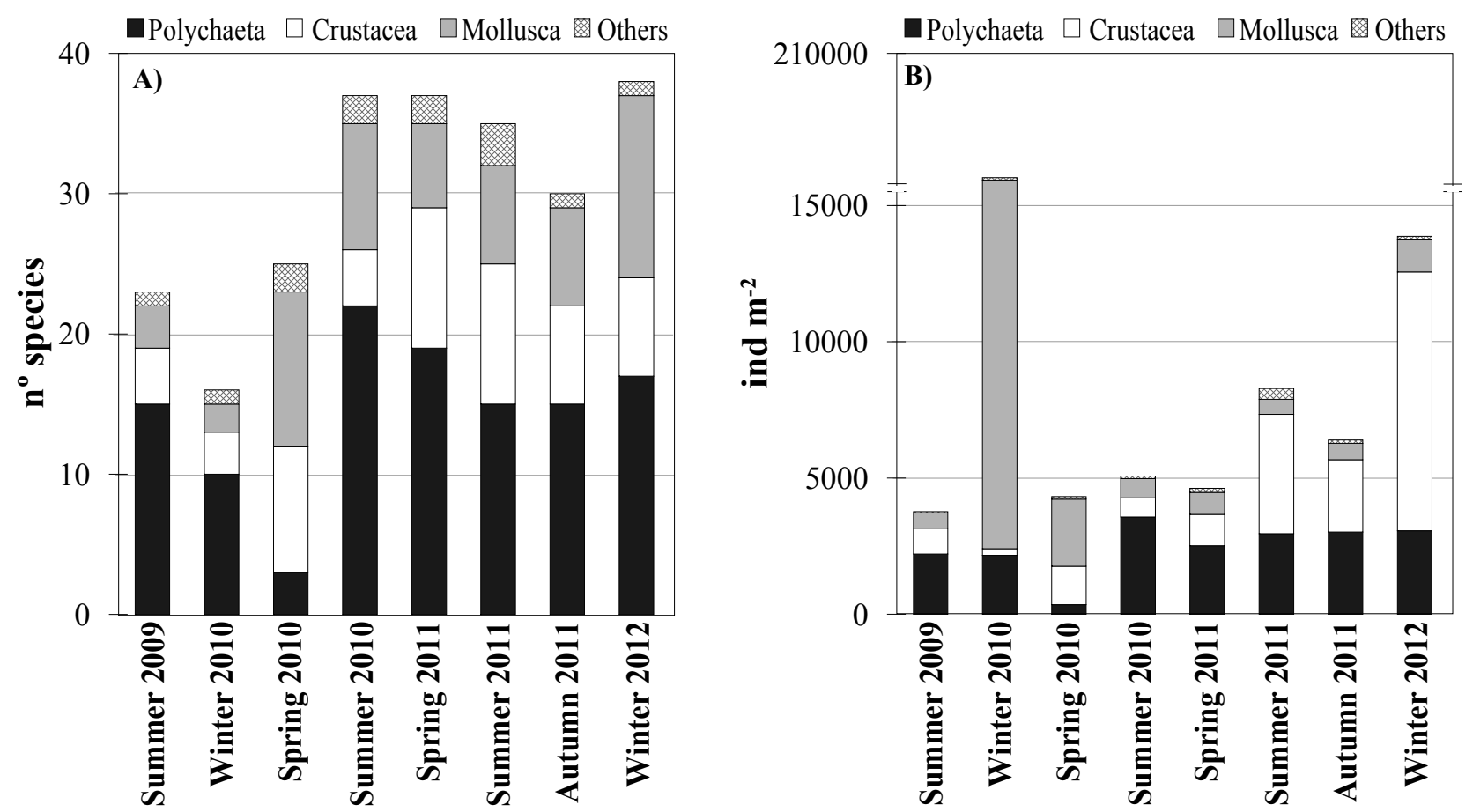

Fig.2. A) Species richness of benthic macrofauna and B) macrofauna density in sampling station sediments in each campaign.

( 2 column fitting image) 

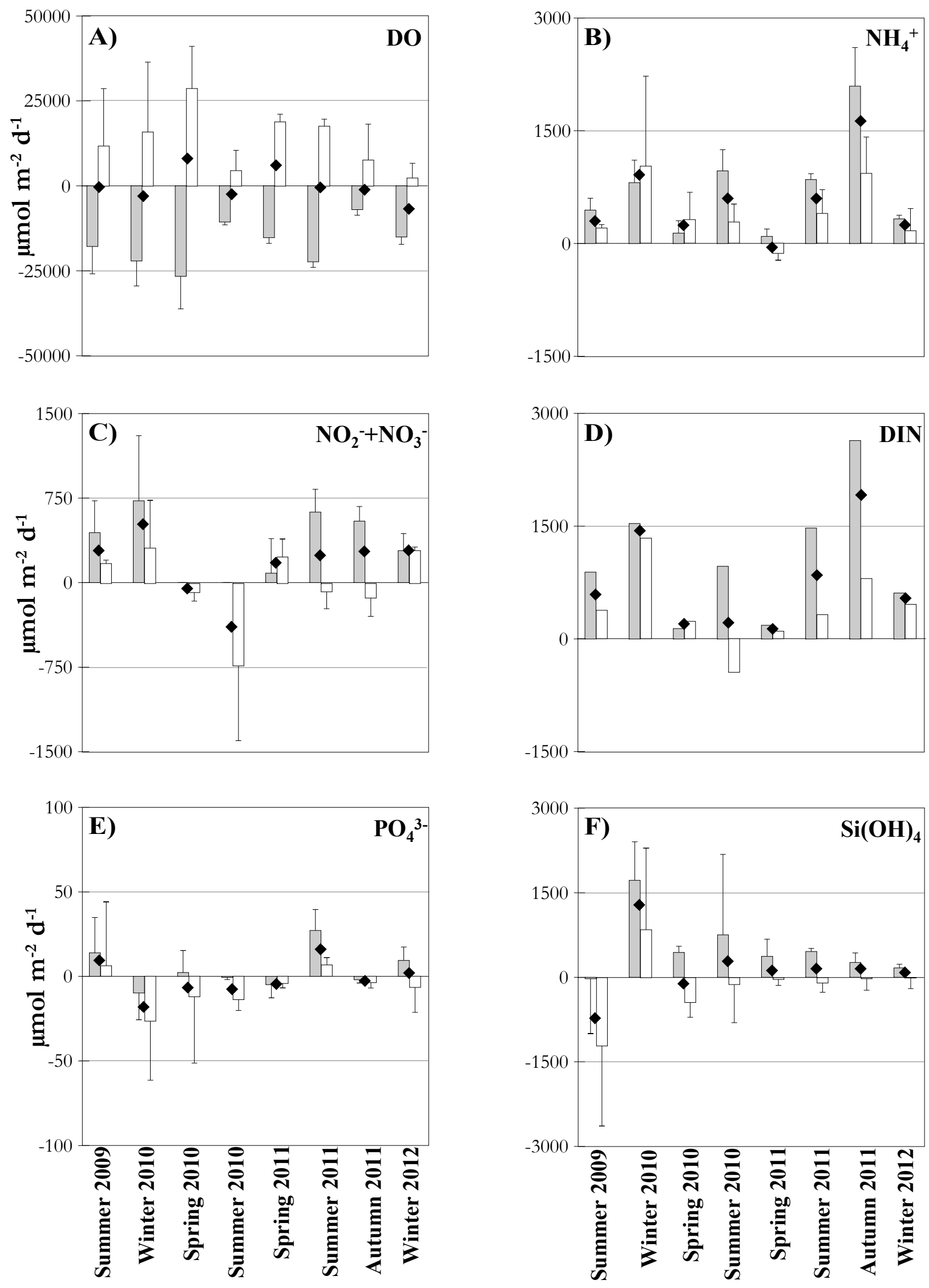

Fig. 3. Benthic fluxes of A) dissolved oxygen (DO), B) ammonium $\left(\mathrm{NH}_{4}{ }^{+}\right)$, C) nitrite and nitrate $\left(\mathrm{NO}_{2}{ }^{-}+\mathrm{NO}_{3}{ }^{-}\right)$, D) dissolved inorganic nitrogen (DIN), E) phosphate $\left(\mathrm{PO}_{4}{ }^{3-}\right)$ and $\mathrm{F}$ ) silicic acid $\left(\mathrm{Si}(\mathrm{OH})_{4}\right)$ in dark (grey bars) and light 
chambers (white bars) with their standard deviation in the eight sampling campaigns. Black diamonds represent daily fluxes.

( 2 column fitting image)

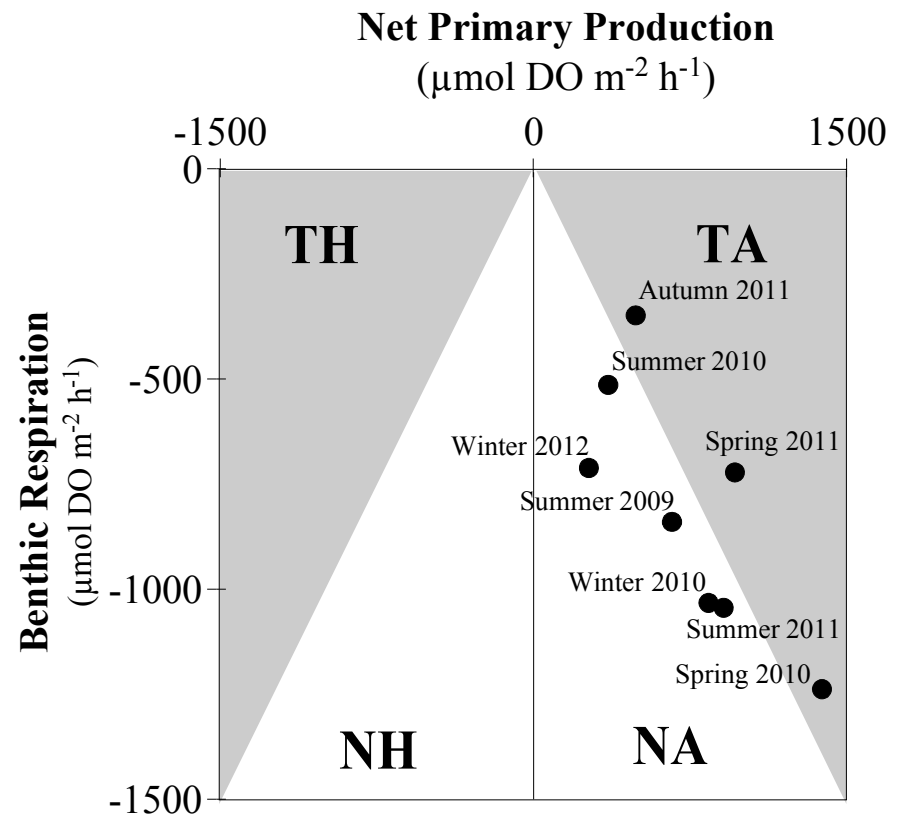

Fig.4. Trophic Oxygen State Index (TOSI; Viaroli et al., 1996) based on benthic respiration and benthic net primary production at sampling station in each campaign. $\mathrm{TH}$ : totally heterotrophic, NH: net heterotrophic, NA: net photoautotrophic, TA: highly photoautotrophic.

(single column fitting image) 